NASA/TM-2009-214177

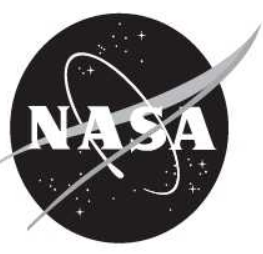

\title{
Modeling the Dynamics and Export of Dissolved Organic Matter in the Northeastern U.S. Continental Shelf
}

\author{
J.N. Druon, A. Mannino, S. Signorini, C.R. McClain, M. Friedrichs, J. Wilkin, and K. Fennel
}


The NASA STI Program Office ... in Profile

Since its founding, NASA has been dedicated to the advancement of aeronautics and space science. The NASA Scientific and Technical Information (STI) Program Office plays a key part in helping NASA maintain this important role.

The NASA STI Program Office is operated by Langley Research Center, the lead center for NASA's scientific and technical information. The NASA STI Program Office provides access to the NASA STI Database, the largest collection of aeronautical and space science STI in the world. The Program Office is also NASA's institutional mechanism for disseminating the results of its research and development activities. These results are published by NASA in the NASA STI Report Series, which includes the following report types:

- TECHNICAL PUBLICATION. Reports of completed research or a major significant phase of research that present the results of NASA programs and include extensive data or theoretical analysis. Includes compilations of significant scientific and technical data and information deemed to be of continuing reference value. NASA's counterpart of peer-reviewed formal professional papers but has less stringent limitations on manuscript length and extent of graphic presentations.

- TECHNICAL MEMORANDUM. Scientific and technical findings that are preliminary or of specialized interest, e.g., quick release reports, working papers, and bibliographies that contain minimal annotation. Does not contain extensive analysis.

- CONTRACTOR REPORT. Scientific and technical findings by NASA-sponsored contractors and grantees.
- CONFERENCE PUBLICATION. Collected papers from scientific and technical conferences, symposia, seminars, or other meetings sponsored or cosponsored by NASA.

- SPECIAL PUBLICATION. Scientific, technical, or historical information from NASA programs, projects, and mission, often concerned with subjects having substantial public interest.

- TECHNICAL TRANSLATION. English-language translations of foreign scientific and technical material pertinent to NASA's mission.

Specialized services that complement the STI Program Office's diverse offerings include creating custom thesauri, building customized databases, organizing and publishing research results ... even providing videos.

For more information about the NASA STI Program Office, see the following:

- Access the NASA STI Program Home Page at http://www.sti.nasa.gov/STI-homepage.html

- E-mail your question via the Internet to help@sti.nasa.gov

- Fax your question to the NASA Access Help Desk at (301) 621-0134

- Telephone the NASA Access Help Desk at (301) 621-0390

- Write to: NASA Access Help Desk

NASA Center for AeroSpace Information 7115 Standard Drive Hanover, MD 21076-1320 


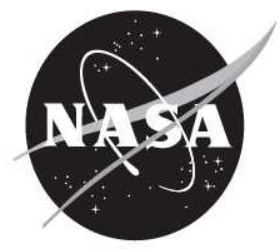

\title{
Modeling the Dynamics and Export of Dissolved Organic Matter in the Northeastern U.S. Continental Shelf
}

\author{
J.N. Druon and A. Mannino \\ NASA Goddard Space Flight Center, Greenbelt, Maryland \\ Sergio R. Signorini \\ Science Applications International Corporation, Beltsville, Maryland \\ Charles R. McClain \\ NASA Goddard Space Flight Center, Greenbelt, Maryland \\ M. Friedrichs \\ Virginia Institute of Marine Science, The College of William \& Mary, Gloucester Point, Virginia \\ J. Wilkin \\ Rutgers University, New Brunswick, New Jersey \\ K. Fennel \\ Dalhousie University, Department of Oceanography, Halifax, Nova Scotia, Canada
}

National Aeronautics and

Space Administration

Goddard Space Flight Center

Greenbelt, Maryland 20771 
Available from:

NASA Center for AeroSpace Information 7115 Standard Drive

Hanover, MD 21076-1320
National Technical Information Service 5285 Port Royal Road Springfield, VA 22161 


\section{Abstract}

Continental shelves are believed to play a major role in carbon cycling due to their high productivity. Particulate organic carbon (POC) burial has been included in models as a carbon sink, but we show here that seasonally produced dissolved organic carbon (DOC) on the shelf can be exported to the open ocean by horizontal transport at similar rates $\left(1-2 \mathrm{~mol} \mathrm{C} \mathrm{m}^{-2} \mathrm{yr}^{-1}\right)$ in the southern U.S. MidAtlantic Bight (MAB). The dissolved organic matter (DOM) model imbedded in a coupled circulation-biogeochemical model reveals a double dynamics: the progressive release of dissolved organic nitrogen (DON) in the upper layer during summer increases the regenerated primary production by 30 to $300 \%$, which, in turns, enhances the DOC production mainly from phytoplankton exudation in the upper layer and solubilization of particulate organic matter (POM) deeper in the water column. This analysis suggests that DOM is a key element for better representing the ecosystem functioning and organic fluxes in models because DOM (1) is a major organic pool directly related to primary production, (2) decouples partially the carbon and nitrogen cycles (through carbon excess uptake, POM solubilization and DOM mineralization) and (3) is intimately linked to the residence time of water masses for its distribution and export. 



\section{Introduction}

Dissolved organic matter (DOM) has received increasing attention over the past few decades because dissolved organic carbon (DOC) represents by far the largest pool of organic carbon in the ocean. DOC export from the surface global ocean is estimated at $20 \%$ of total organic carbon flux to the deep ocean (Six and Maier-Reimer, 1996; Hansell, 2002), which represents an important control on atmospheric carbon dioxide levels (i.e., the biological pump). Particulate organic carbon (POC), which accounts for $80 \%$ of the organic carbon export in the open ocean, is mainly recycled on the shelf and fuels the DOC pool. If residence times of shelf waters are shorter than the lifetime of much of the seasonally produced DOC, the horizontal DOC flux could represent the main contribution to the export of organic carbon to the open ocean and exceed sinking POC fluxes (Bauer and Druffel, 1998).

The Mid-Atlantic Bight (MAB) is the central region of the eastern U.S. continental shelf characterized by high rates of primary productivity and strong residual circulation. This region is thus a potential area of organic carbon export to the open ocean. The DOC pool in the MAB is one to three orders of magnitude larger than the POC pool (Bauer, 2001). The hydrography and circulation of the MAB is well studied (Biscaye et al., 1994) with a general north to south flow from Georges Bank to Cape Hatteras. The greatest inflow of water to the MAB (0.4 Sv, Beardsley and Boicourt, 1981) is from Georges Bank and is characterized by relatively low temperature and salinity. This flow represents the southern extension of the Labrador Current with averaged (total) DOC concentrations between 72 and $75 \mathrm{mmol} \mathrm{m}^{-3}$ (Vlahos et al., 2002). In the southern MAB near Cape Hatteras, the warm and salty water of the Gulf Stream has a major impact on the flow and exchange of water on the shelf and slope. Although the mean circulation is along-shelf in the southwestward direction, cross-shelf exchanges due to frontal instabilities and eddies displace significant portions of the shelf water to the open ocean north of Cape Hatteras (Biscaye et al., 1988). The freshwater inflow $(0.005 \mathrm{~Sv})$ to the MAB is about $1 \%$ of the total water inflow (Beardsley and Boicourt, 1981), but represents a significant input of total DOC with mean concentrations of 200 to $400 \mathrm{mmol} \mathrm{C} \mathrm{m}^{-3}$ in the mid-Bay of the Chesapeake Bay (data from the Chesapeake Bay Program, http://www.chesapeakebay.net/wquality.htm) throughout the year and 90 to $190 \mathrm{mmol} \mathrm{C} \mathrm{m}^{-3}$ in the mouths of the MAB estuaries (Bates and Hansell, 1999; Fisher, 1998; Harvey and Mannino, 2001; Sharp et al., 1982; Taylor, 2003). Terrestrial DOC fluxes and composition in the MAB region were investigated (Delaware Bay, Mannino and Harvey, 2000a; b; Chesapeake Bay, Mitra et al., 2000; MAB, Aluwihare et al., 2002). Strong gradients in DOM concentration exist between estuarine, shelf and open ocean waters (Hopkinson et al., 2002; Vlahos et al., 2002). The DOM concentrations on the shelf are elevated compared to the open ocean and contain a larger labile fraction and younger DOC (Bauer, 2002) than DOM in deep slope waters, where carbon is more refractory and enriched relative to nitrogen and phosphorus (Hopkinson et al., 2002). Because half-lives of the labile DOM pool are on the order of shelf-water residence time, a substantial pool of DOM that is depleted in nitrogen and phosphorus relative to carbon remains and a net export of DOC to the open ocean can occur by advective and eddy diffusive processes (Hopkinson et al., 2002). A DOC budget study based on field measurements estimated a total export from the MAB shelf to the open ocean of 18.7-19.6 Tg.C.yr ${ }^{-1}$ (Vlahos et al., 2002). To our knowledge, there has been no attempt to model the DOC dynamics and fluxes in the MAB. 
DOM is believed to play an important role in carbon and nitrogen cycling from regional to global scales. DOM production is known to confound eutrophication issues (e.g. mucilage events) and may contribute to climate regulation by impacting carbon cycling and sequestration. Models have included DOM to study eutrophicated (Lancelot et al., 2005), eutrophic (upwelling, Ianson and Allen, 2002), mesotrophic (Anderson and Williams, 1998; Fasham et al., 1999) and oligotrophic (Anderson and Pondaven, 2003; Raick et al., 2005) regional systems and the global ocean (Popova and Anderson, 2002). Fasham et al. (1999) demonstrated that accounting for DOC is essential for euphotic ecosystem models and development of a carbon budget. Because DOC and DON dynamics are partially decoupled (e.g. carbohydrate production, mineralization rates), these models explained important deviations from the Redfield ratio in terms of productivity and export fluxes, and sustained nutrient-based primary production through DON mineralization and atmospheric inputs (Seitzinger and Sanders, 1999).

The goal here is to describe the main pathways of DOM from production to mineralization in the MAB and to estimate the horizontal export of semi-labile DOC to the open ocean. This paper is organized as follows. After a brief description of the coupled physical-biogeochemical model, the DOM modeling is detailed (Section 2), the model validation and results will be presented (Section 3) and discussed (Section 4) with a focus on DOM dynamics and carbon export to the open ocean. This work is part of the Interdisciplinary Project USECoS, Eastern U.S. Continental Shelf Carbon Budget, for which a complete overview is presented in Hofmann et al. (2008).

\section{Model description}

\subsection{The physical model}

The three-dimensional ocean circulation model (ROMS, Regional Ocean Modeling System version 3) extends across the Northeast North American (NENA) shelf including the Scotian shelf, the Gulf of Maine, the MAB, the South Atlantic Bight (SAB), the Eastern Gulf of Mexico and the adjacent deep sea (Figure 1). The focus of this paper is on the MAB and Georges Bank regions of the continental margin (Figure 1). The NENA model is nested within a North Atlantic (NA) model in order to capture large circulation features and variability such as the Labrador Current, the Gulf Stream and associated subtropical gyre circulation.

ROMS (Haidvogel et al., 2000, Haidvogel, 2007) is a model widely used for shelf circulation and coupled physical-biological applications (e.g., Dinniman et al., 2003; Marchesiello et al., 2003; Peliz et al., 2003; Fennel et al. 2006; Wilkin, 2006). The ROMS computational kernel produces accurate evolution of tracer fields - a particularly attractive feature for biogeochemical modeling because it facilitates accurate interaction among tracers and accounting of total nutrient and carbon budgets. The application on the NENA domain uses a $10-\mathrm{km}$ horizontal resolution and 30 terrain-following vertical levels stretched to give high resolution in surface and bottom boundary layers. This resolution is sufficient to capture the dominant dynamics governing shelf-wide circulation, yet is coarse enough to allow multiple simulations that explore sensitivities within the ecosystem model. Open boundary temperature, salinity and sub-tidal frequency velocity are taken from 3-day averages of the Hybrid Coordinate Ocean Model data assimilation product developed as part of the Global Ocean Data Assimilation Experiment North Atlantic Basin 'best-estimate' analysis for 2003-present. Tides have been introduced at the boundary using harmonic data from the Oregon State University Topex/Jason altimeter data inversion and a surface gravity wave radiation scheme (Flather, 1976). Air-sea heat and momentum fluxes are computed using bulk formulae (Fairall et al., 2003) applied to 


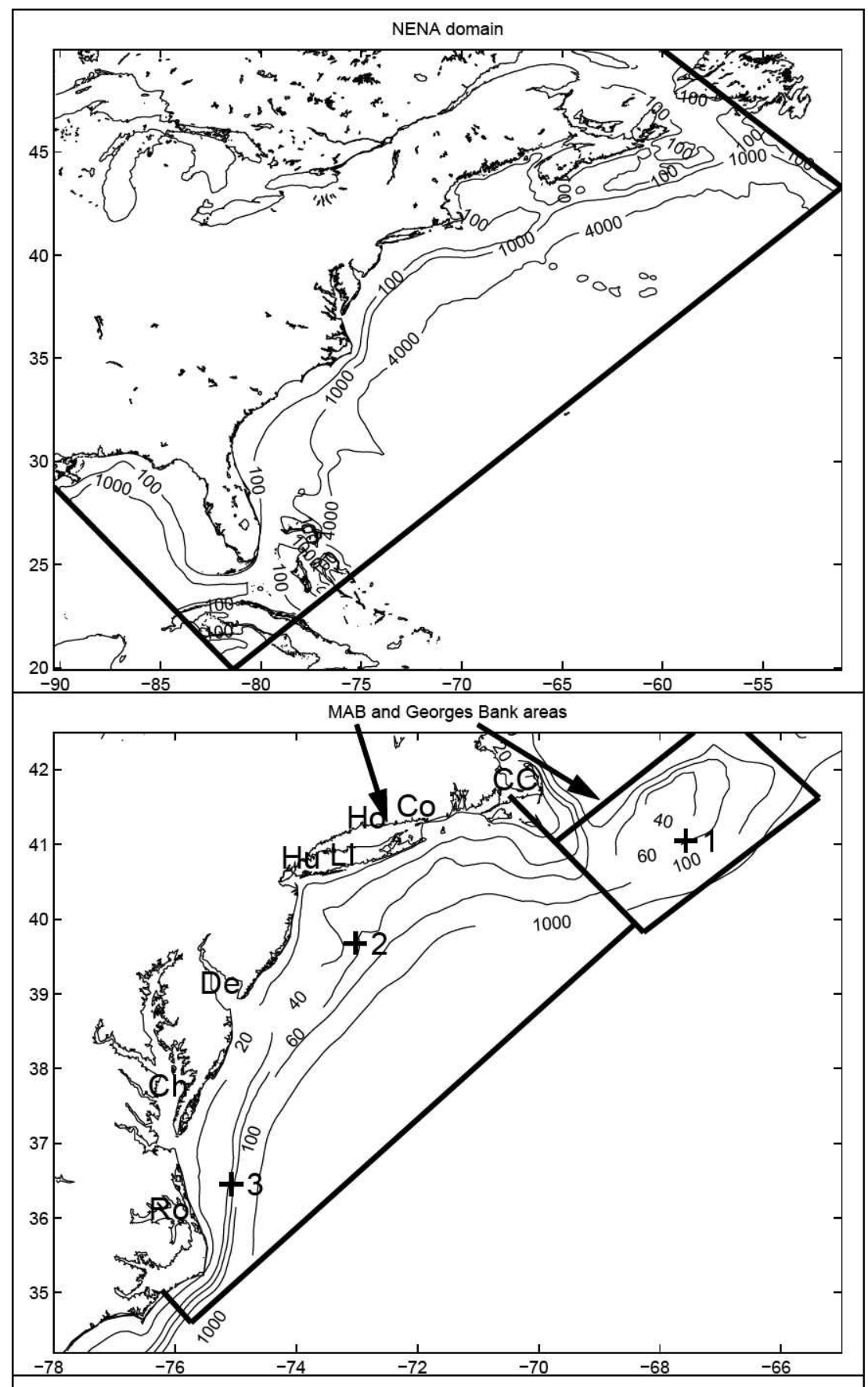

Figure 1. Geographical location and bathymetry (in meters) of the NENA (upper graph) and details of the MAB and Georges Bank regions (bottom The three numbered stations cited in the text are also shown. The locations the text are: 'CC' Cape Cod, 'Co' Connecticut River, 'Ho' Housatonic Riv Long Island, 'Hu' Hudson River, 'De' Delaware Bay, 'Ch' Chesapeake Ba Roanoke River. model sea surface conditions, and air temperature, pressure, humidity and winds from daily average National Center for Environmental Prediction re-analysis fields. Vertical turbulent mixing closure uses the parameterization of Mellor and Yamada (1982) and Warner et al. (2005). Coastal freshwater inputs are applied using USGS river flow data.

This model exhibits recognized features of local and remotely forced circulation on the shelf and slope. These include wind-driven upwelling in the MAB and SAB, buoyancy-driven river plumes, tidal mixing and tidal residual mean currents on Georges Bank, southwestward mean flow in the MAB, low salinity on the MAB inner shelf, and retention of passive particles in the shelf-slope front. In addition the model captures Gulf Stream intrusions in the $\mathrm{SAB}$, and interactions of Gulf Stream warm rings with the New England slope (Hofmann et al. 2008).

The simulations described below use a higher background value for diffusivity $\left(10^{-5} \mathrm{~m}^{2} \mathrm{~s}^{-1}\right)$ than in Fennel et al. $\left(2006,10^{-6} \mathrm{~m}^{2} \mathrm{~s}^{-1}\right)$ to compensate for the lack of secondary mixing processes such as internal waves and sub-grid turbulent diffusion. Similar background levels of diffusivity were shown to be necessary to reproduce the vertical temperature field and have been used in other model applications as well $\left(10^{-}\right.$ ${ }^{5} \mathrm{~m}^{2} \mathrm{~s}^{-1}$, Kantha and Clayson,

1994, and $2.10^{-5} \mathrm{~m}^{2} \mathrm{~s}^{-1}$, Ledwell et al., 1993). 


\subsection{The biogeochemical model with DOM}

A general overview of the biogeochemical model schematic is presented in Figure 2 and the full details of the governing equations including the semi-labile DON and DOC are presented in the Appendix. The biogeochemical model includes the dynamics of nitrogen and carbon cycling. The semi-labile DOC and DON were added as state variables to the nitrogen-based model of Fennel et al. (2006) and the inorganic carbon component described in Fennel et al. (submitted). The nitrogen model includes eight state variables: nitrate (NO3), ammonium (NH4), phytoplankton (Phy), semilabile DON (named hereafter $D O N$ ), zooplankton (Zoo), small and large detritus (SDet $N$ and $L D e t N$ ) and phytoplankton chlorophyll $(C h l)$. The nitrogen-cycling formulations used here are the same as those in Fennel et al. (2006), except for several processes and parameters such as the resuspension and burial of POM (see Appendix and Table A2) which were required to meet the requirements of the DOM equations. The carbon model includes dissolved inorganic carbon (DIC), semi-labile DOC (named hereafter $D O C$ ) and small and large detritus (SDetC and $L D e t C$ ). Phytoplankton and zooplankton are expressed implicitly in carbon units using the nitrogen unit equation and their specific $\mathrm{C}$ to $\mathrm{N}$ ratio $\left(C N_{P}\right.$ and $C N_{Z}$ respectively), thus no explicit equations are required (see Appendix). The DIC dynamics and air-sea exchange of carbon dioxide are described in Fennel et al. (submitted).

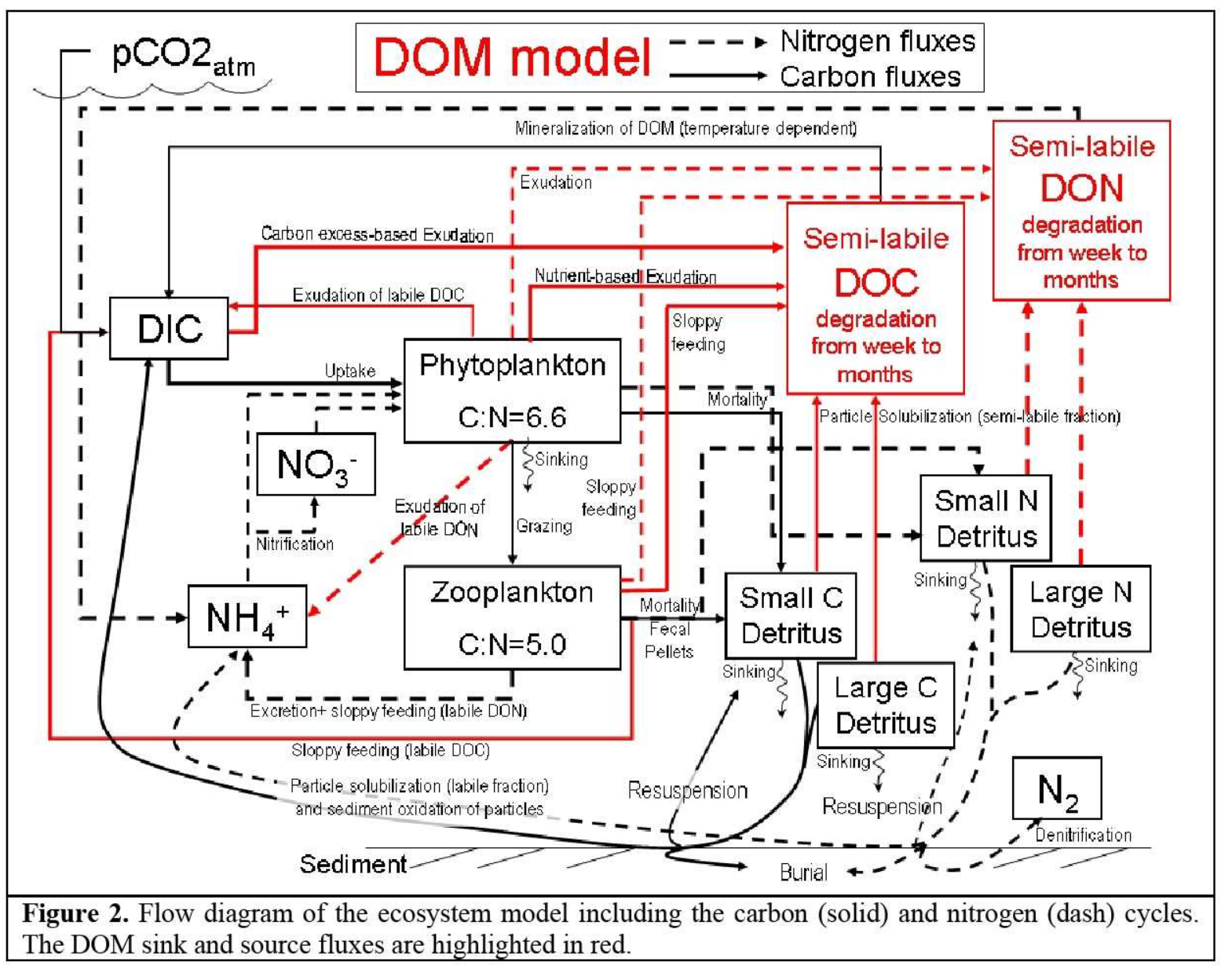




\section{Semi-labile DOC and DON lability}

The definition of the DOC and DON pools may vary significantly between authors, therefore a definition is provided here in relation with the scales involved and goal pursued. The DOM pool is generally divided into labile, semi-labile and refractory pools although a continuum of biological lability exists between these categories (Amon and Benner, 1996). Highly variable decomposition (or turnover) rates of DOC were measured for surface and bottom waters of the MAB (Hopkinson et al., 2002). The refractory pool has a very long turnover time (several thousand years on average, Druffel et al., 1992; Santschi et al., 1995) and its concentration is relatively constant in the surface ocean at the yearly time scale. Although the refractory DOM represents $71 \%$ of the total DOC pool and $61 \%$ of the total DON pool in the shelf and slope water of the MAB (Hopkinson et al., 2002), the model does not take into account its variability since this study concentrates on the seasonal production of DOM. The labile material is defined here as having a turnover time scale of a few days to hours. Since it is mineralized in a few days within the $10 \mathrm{~km}$-grid box of the model, the labile DOM is directed to the dissolved inorganic compartments $\left(\mathrm{DIC}\right.$ and $\left.\mathrm{NH}_{4}\right)$. The semi-labile fraction simulated by the model has a turnover time of one week to several months (due to a temperature dependency), which is on the order of the shelf residence time in the MAB ( 100 days). As such this defined semi-labile DOM can therefore be efficiently exported to the open ocean by horizontal transport.

\section{DOM production by phytoplankton}

An overview of the literature highlights two phases of DOC production by phytoplankton. Søndergaard et al. (2000) suggest in their study that exponentially growing communities produce the most labile DOC, whereas declining and nitrogen-deficient communities produce the least labile DOC. During the growth phase, DOM production is linked to biomass and dominated by the exudation of labile-low molecular weight (LMW) organic compounds (Biddanda and Benner, 1997; Jensen, 1983; Lancelot, 1984) with a $\mathrm{C}$ to $\mathrm{N}$ ratio of $\sim 7$ (range 3-11 depending on species [ 6.6 for the diatom sp. skeletonema], Biddanda and Benner, 1997). In fact, the exudation was shown to be a passive diffusion across the outer cell membrane that occurs as long as new products of photosynthesis are available (Marañón et al., 2004). During the stationary and decaying phase of the bloom (i.e. under nutrient stress), large quantities of semi-labile, high molecular weight (HMW) DOM with high C to $\mathrm{N}$ ratios (10-25 compiling results from Benner et al. (1992)) would be released as a result of the exudation of polymeric carbohydrates (Lancelot and Billen, 1985) or due to cell lysis and to 'sloppy' feeding by zooplankton.

Some evidence suggests that the release of carbohydrates by phytoplankton could mainly explain the accumulation of semi-labile DOC after the spring bloom and its progressive remineralization during summer and autumn. Biddanda and Benner (1997) showed that the relative abundance of carbohydrates in phytoplankton DOC increased from $23 \%$ during the exponential phase to $80 \%$ during the decay phase. Continued maintenance of photosynthetic machinery after nutrient exhaustion was found to be accompanied by excretion of DOM and especially carbohydrates with high C to N ratio (Hellebust, 1965; Norrman et al., 1995). Diatoms can continue to excrete polysaccharides for a considerable time after the halt of cellular protein synthesis (Jensen, 1983). In many offshore systems, a DOC decrease is found to continue after nutrient exhaustion (Sambrotto et al., 1993). The semi-labile DOC release would thus occur mainly in low nutrient conditions and is likely to be associated with phytoplankton primary production. Furthermore, Thingstad et al. (1997) proposed that the spring to summer accumulation of DOC is related to microzooplankton grazing on 
bacteria coupled to low bacterial growth rates, which would reduce DOC remineralization and allow DOC accumulation.

Two models of extracellular DOM release have been proposed: the overflow model (Fogg, 1966; 1983; Nagata, 2000; Williams, 1990) and the passive diffusion model (Bjørnsen, 1988; Fogg, 1966) . Even if these models were opposed in conflicting reports, it is likely that they are not mutually exclusive and that both models are correct given the right environmental conditions and plankton community structure (Carlson, 2002). Carlson suggests that the extracellular release of labile-LMWDOM model is likely to be a passive diffusion process linked to biomass. During the stationary and decay phases, the overflow model is likely to represent an active release of semi-labile-HMW-DOM linked to primary production and enhanced in a nutrient-depleted environment. Because primary production is traditionally expressed in models as a function of biomass, both terms of exudation (labile) and excretion (semi-labile) of DOM are dependent on primary production in the present model (and in most other modeling studies, e.g. Anderson and Williams, 1998). This option allows in addition an easier interpretation of the model results.

\section{Exudation of labile DON and nutrient-based labile DOC}

Admiraal et al. (1986) estimated that approximately 3\% of assimilated nitrate is excreted as amino acids. The rate chosen for the labile DON exudation (and instantaneous mineralization in the model) is set to $\omega_{N}=3 \%$ of phytoplankton nitrogen production. The labile DOC leakage is also expressed as a function of primary production with the same rate $\left(\omega_{C}=3 \%\right)$ to ensure a constant Redfield ratio for labile DOM and phytoplankton.

\section{Semi-labile DON exudation by phytoplankton}

Bronk et al. (1994) found an average DON release of 25 to $41 \%$ of the inorganic nitrogen uptake in offshore oceanic (25\%), coastal (27\%) and estuarine (41\%) environments with turnover times of 10 $\pm 1,18 \pm 14$, and 4 days respectively. Søndergaard et al. (2000) found $25 \%$ in their mesocosm study. Since the labile fraction of DON production is estimated to be a few percent of DIN uptake (see above), the semi-labile DON total release in the coastal ocean is most probably in the range of 22 to $24 \%$ of nitrogen-based primary production with decreasing value towards offshore. Varela et al. (2003) provided some evidence that DON production is dominated by grazing processes rather than by direct phytoplankton excretion. Large DON losses ( $>50 \%$ of nitrogen uptake) were attributed to intense grazing and sloppy feeding for several marine ecosystems (Bronk and Ward, 2000). The maximum of DON release was found to occur when small, presumably heterotrophic, flagellates dominated the biomass and not the primary production (Varela et al., 2003), i.e. sloppy feeding by flagellates could significantly increase the DON release. In summary, sloppy feeding might dominate the DON release during a short period of intense grazing, but phytoplankton exudation and detritus solubilization dominates otherwise. It is estimated that the DON released by exudation follows a Redfield ratio of the nutrient based DOC exudation that is set to $4 \%$ of primary production (basal value of DOC exudation by healthy phytoplankton, see next subsection). The rate of semilabile DON exudation by phytoplankton $\left(\varepsilon_{N}\right)$ is set to $4 \%$ of nitrogen-based primary production. Following the above assumption that semi-labile DON release should be about $22 \%$ of primary production, the sloppy feeding should account for about 2 to $14 \%$ (low and high grazing) and PON solubilization for about 16 to $4 \%$ depending on grazing. 


\section{Nutrient and carbon excess-based semi-labile DOC exudation by phytoplankton}

In their mesocosm experiment, Norrman et al. (1995) observed that $23 \%$ of total new production accumulated as DOC, which was found to increase due to a combination of excretion and cell lysis. A large range of values of DOC production as a fraction of primary production can be found in the literature (5-30\%, Biddanda and Benner 1997, Norman et al. 1995), however excretion from natural healthy phytoplankton was found to be lower (4-16\%) than at the end of a diatom bloom (17-38\%, Hellebust 1965).

Two terms describe the semi-labile DOC exudation by phytoplankton in the model: a nutrient-based and carbon excess-based release. The nutrient-based release reflects the healthy phytoplankton exudation of semi-labile DOC and follows the semi-labile DON exudation with the Redfield ratio. The carbon excess-based release represents the carbohydrate over-production by nutrient-stressed cells. The carbon excess uptake is seen as an 'overflow' of photosynthesis under nutrient limitation. It is formulated as the difference between the nutrient-saturated (light-limited) and nutrient-limited (light-limited) primary production and is directed to the semi-labile DOC (Andersen and Williams 1998, Ianson and Allen 2002, see Figure 3 with the details of the terms in Table 1). The carbon excess uptake $\left(U_{\text {exc. } C}\right)$ is thus expressed:

$$
U_{\text {exc. } C}=\gamma C N_{P}\left(P P_{L}-P P_{L} L_{N}\right)
$$

where $P P_{L}$ is the nutrient-based primary production limited by light, $L_{N}$ is the nutrient limitation, $C N_{P}$ is the $\mathrm{C}$ to $\mathrm{N}$ ratio for phytoplankton and $\gamma$ the parameter of carbon excess-based DOC excretion by phytoplankton. A fraction $\left(\sigma_{c}\right)$ of the carbon excess uptake is directed to the semi-labile DOC pool and represents the exudation of carbon excess-based DOC release. This fraction is set to $\sigma_{c}=0.45$ (Biddanda and Benner, 1997 found $\sim 35 \%$ ). The labile DOC originating from carbon excess uptake represents a slightly higher fraction $\left(1-\sigma_{c}\right)$ and is directed back to DIC.

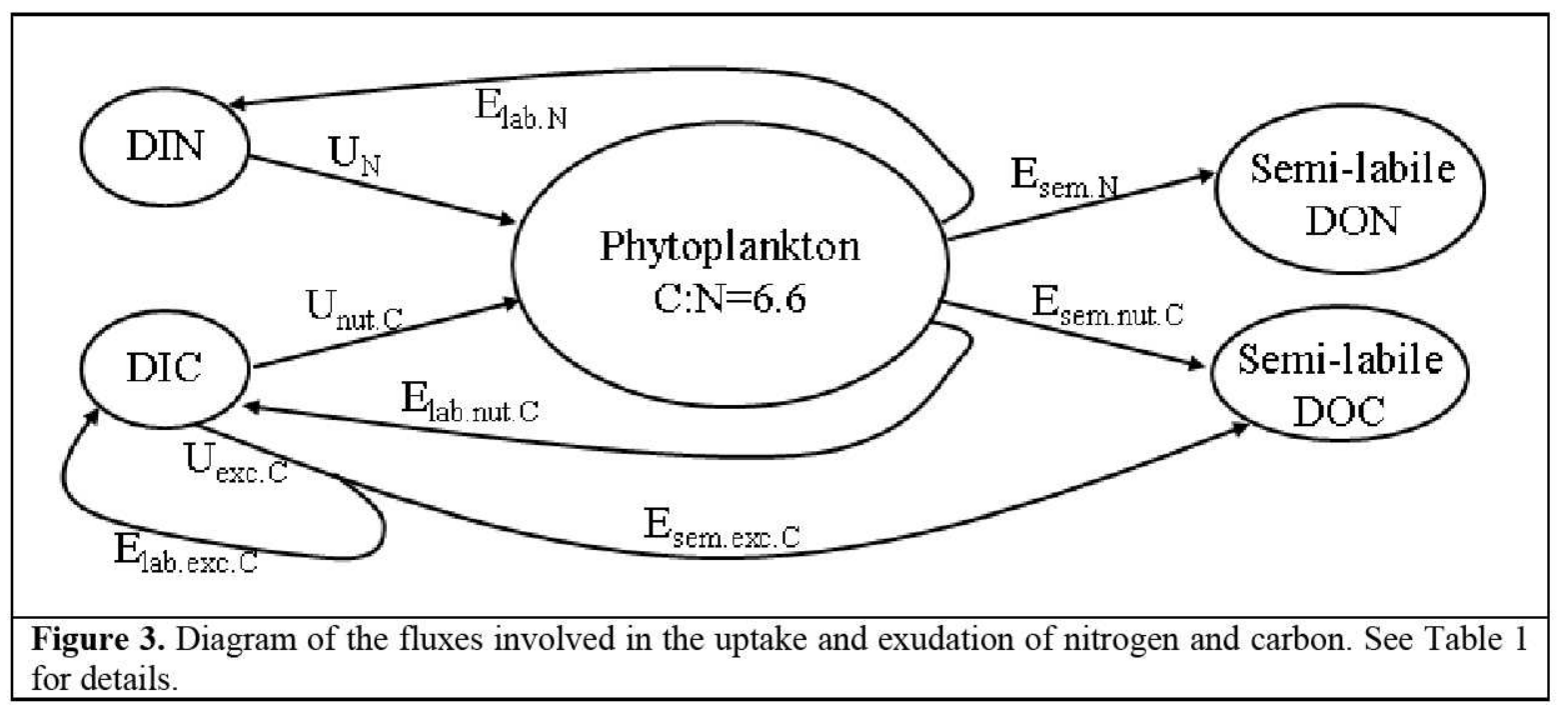

The total excretion is commonly expressed as a fraction of the total carbon fixed by phytoplankton, the percentage extracellular release (PER). In the present setting, the PER follows: 


$$
\operatorname{PER}=100\left(\frac{\mathrm{E}_{\text {lab.nut.C }}+\mathrm{E}_{\text {sem.nut.C}}+\mathrm{E}_{\text {lab.exc.C }}+\mathrm{E}_{\text {sem.exc.C }}}{\mathrm{U}_{\text {nut.C }}+\mathrm{U}_{\text {exc.C }}}\right)=100\left(1-\frac{1-\omega_{N}-\varepsilon_{N}}{1+\gamma\left(\frac{1}{L_{N}}-1\right)}\right)
$$

The PER for diatoms was estimated to be between 10\% and about 55\% (Baines and Pace, 1991; Obernosterer and Hernd1, 1995) with an increase between the exponential and the stationary phase of the bloom. Higher PER values (70-80\%) were observed in eutrophic water for Phaeocystis pouchetii (Lancelot, 1983). The analytical formulation of the PER in our model shows that the mean PER is lower than $65 \%$ for $L_{N}$ below 0.5 (nutrient limiting condition) when $\gamma$ is set to 0.20 . We thus chose $\gamma$ $=0.20$ for the simulations. For comparison, Anderson and Williams (1998) adjusted $\gamma$ to 0.26 to achieve the desired spring DOC concentration and obtained PER values between $10 \%$ and $60 \%$ for Station E1 in the English Channel.

\section{DOC release by 'Sloppy' feeding}

Measurements from the literature suggest a high DOC release when the prey is large relative to the copepod and low DOC release when the prey is small relative to the copepod (Møller, 2005). During a diatom bloom, sloppy feeding was, by far, the most important contributor to the DOC production by Calanus spp., and $49 \%$ of the carbon removed from suspension by the copepods was returned to the water column as DOC (Møller et al., 2003). Møller (2005) found a significant relationship between the DOC production through sloppy feeding by zooplankton and the copepod-to-prey size ratio. $Q$ defines the fraction of prey carbon removed from suspension and lost as DOC for copepod:prey size ratio below 55 :

$$
Q=0.714-0.013\left(\frac{E S D_{\text {copepod }}}{E S D_{\text {prey }}}\right) \text { where } E S D \text { is the equivalent spherical diameter. }
$$

According to Møller et al. (2003), when copepods graze large diatom cells in spring the copepod:prey size ratio can reach a minimum of 10 and $Q$ values may reach $71 \%$. For an increasing size ratio, i.e. when copepods graze on smaller prey during summer, $Q$ decreases linearly down to $Q=0.1 \%$ for a size ratio of 55 (or more). In agreement, Møller (2005) illustrates that when the prey is large relative to the copepod, i.e. during a bloom of large cells, copepods lose significant amounts of dissolved material. In contrast, the link between copepod feeding and energy flow to higher trophic levels is tighter when the prey is small, i.e. during oligotrophic periods when small cells dominate the phytoplankton prey. The fraction of DOC released by sloppy feeding is likely to reach its maximum during the spring bloom (large diatoms) and minimum in summer when smaller cells are grazed. Since a high grazing level is a good proxy of high biomass of large cells (diatom spring bloom), a linear relationship is used to enhance the fraction of DOC release by sloppy feeding at high grazing levels:

$$
Q_{D O C}=0.71\left(\frac{g}{g_{\max }}\right)=0.71\left(\frac{P h y^{2}}{k_{p}+P h y^{2}}\right)
$$


where $g$ is the grazing, $g_{\max }$ is the maximum grazing rate, $g=g_{\max } \frac{P h y^{2}}{k_{p}+P h y^{2}}$ (Fennel et al., 2006) and $k_{p}$ is the half-saturation constant of phytoplankton ingestion. The maximum fraction of DOC release of $71 \%$ is thus encountered when the grazing intensity is maximum, i.e. at the highest levels of phytoplankton biomass.

The fraction of semi-labile DOC (to total DOC) in the phytoplankton cell is estimated using the work of Biddanda and Benner (1997). They estimated that dissolved carbohydrates represent the major part of cell DOC during the stationary phase of the bloom. They measured a fairly stable fraction of dissolved polysaccharide carbohydrate (between 78 and $94 \%$ with a mean of $85 \%$ ) compared to dissolved monosaccharide carbohydrate between the exponential growth and the stationary phase. However, dissolved polysaccharides (particularly fresh material) can be rather labile (Mannino, 2000; Mannino and Harvey, 2000a), therefore the fraction of semi-labile DOC compared to labile DOC is set to $\delta_{\mathrm{C}}=55 \%$. Although the cell-content of DOC is constant in the model, Biddanda and Benner (1997) measured an increase of dissolved carbohydrates from 23 to $80 \%$ of cell DOC for four phytoplankton groups (Synechococcus, Phaeocystis, Emiliana and Skeletonema) from the growth to the decay phase. The sloppy feeding related terms for carbon are therefore the following:

Assimilation of organic carbon by zooplankton

Semi-labile DOC release by sloppy feeding

Labile DOC (towards DIC) release by sloppy feeding

Fecal pellets production (to large detritus)

where $\beta$ is the zooplankton assimilation rate.

$$
\begin{aligned}
& =C N_{P} \beta g \\
& =C N_{P}(1-\beta) Q_{D O C} \delta_{C} g \\
& =C N_{P}(1-\beta) Q_{D O C}\left(1-\delta_{C}\right) g \\
& =C N_{P}(1-\beta)\left(1-Q_{D O C}\right) g
\end{aligned}
$$

\section{DON release by 'sloppy' feeding}

Hasegawa et al. (2001) found that 9 to $75 \%$ of ingested nitrogen is assimilated in zooplankton biomass depending on food concentration. Therefore, from 25 to $91 \%$ of grazed nitrogen is released as PON, DON or ammonium for low and high food concentrations respectively through the processes of sloppy feeding, excretion and egestion of fecal pellets. Zooplankton excretion rates in the original model (Fennel et al., 2006) included the assimilation related excretion $\left(l_{E}=0.1 \mathrm{~d}^{-1}\right.$ if grazing is maximum) and the basal metabolism related excretion $\left(l_{B M}=0.1 \mathrm{~d}^{-1}\right)$. The rate of fecal pellet production was set to $25 \%$ and the assimilation efficiency to $75 \%$. Therefore, in order to compare with the values of Hasegawa et al. (2001), the fraction of nitrogen released per day in the model by excretion (assuming zooplankton ingests $60 \%$ of its weight of prey per day ${ }^{1}$ ) and egestion of fecal pellets was $0.1 * 0.75+0.1 * 0.6+0.25=0.385$. This value can decrease to $28.5 \%$ if the zooplankton stops grazing. Therefore the model absolute assimilation efficiency ranged from $61.5 \%$ for high food condition to $71.5 \%$ under low food condition, which is a low range for DON release compared to Hasegawa et al. (2001, 9-75\% assimilation). Adding the process of sloppy feeding has the effect of decreasing the absolute assimilation efficiency for high food condition, with a maximum contribution of about $50 \%$ of the nitrogen grazed. The assimilation efficiency in the model was constant and linked to fecal pellet production $(\beta=0.75)$. Compared to the original model, $\beta$ is grazing-dependant taking into account the loss of DON by sloppy feeding. IN the current model, the 'absolute' assimilation efficiency (which includes the excretion rates, $\beta-l_{E} \beta g / g_{\text {max }}-l_{B M}$ ) varies between 10 and $75 \%$ as a function of the grazing intensity (Hasegawa et al., 2001), which leads to:

\footnotetext{
1 The maximum grazing rate is $0.6 \mathrm{~d}^{-1}$.
} 


$$
\beta=\frac{\left[0.75+l_{B M}-0.65 \frac{g}{g_{\max }}\right]}{\left[1-l_{E} \frac{g}{g_{\max }}\right]}
$$

where $\beta$ is the grazing-based assimilation efficiency (excluding the excretion rates). The assimilation efficiency defined here does not include the excretion rates and varies between $\beta=0.22$ for $g=g_{\max }$ and $\beta=0.85$ for $g=0$. The fraction of semi-labile DON to total DON is assumed to be low (the opposite for DOC) and is set to $\delta_{N}=30 \%$. $Q_{D O N}$ being the fraction of total DON to (DON+PON) within the phytoplankton cell, a fraction $\left(1-Q_{D O N}\right)$ of the remaining non-assimilated material $(1-\beta)$ is allocated to the fecal pellets and the complementary fraction $\left(Q_{D O N}\right)$ lost by sloppy feeding to the DON. Seventy percent $\left(1-\delta_{N}\right)$ of this last fraction is labile and $30 \%\left(=\delta_{N}\right)$ is the semi-labile DON. In summary, the grazing term for nitrogen is divided as following:

Nitrogen assimilation for zooplankton

Semi-labile DON release by sloppy feeding

Labile DON release by sloppy feeding

Fecal pellets production (to large detritus)

$$
\begin{aligned}
& =\beta g \\
& =(1-\beta) Q_{D O N} \delta_{N} g \\
& =(1-\beta) Q_{D O N}\left(1-\delta_{N}\right) g \\
& =(1-\beta)\left(1-Q_{D O N}\right) g
\end{aligned}
$$

The $\mathrm{C}$ to $\mathrm{N}$ ratio of semi-labile DOM produced by sloppy feeding in the model, deduced analytically using the terms defined above, has the constant value of $12.1\left(C N_{P} \delta_{C} / \delta_{N}\right)$ using the current parameter set (see Appendix).

\section{Solubilization of carbon and nitrogen detritus}

Smith et al. (1992) showed that bacteria attached to aggregates can express high levels of hydrolytic ectoenzymes which results in the release of DOM. They suggest a preferential solubilization of nitrogen detritus over carbon detritus in agreement with the observed increase in $\mathrm{C}$ to $\mathrm{N}$ and $\mathrm{C}$ to $\mathrm{P}$ ratios of sedimenting material with depth. In the experiments, the aggregates released mainly dissolved combined amino acids (DCAA). Solubilization was uncoupled from bacterial uptake, with $50-98 \%$ of the DCAA released escaping rapid utilization from attached bacteria. From the data estimated by Smith et al. (1992, Table 2), DON release rates from aggregates are calculated assuming a $\mathrm{C}$ to $\mathrm{N}$ ratio for POM of $\sim 5$ as observed by Harvey et al., 1995). The solubilization rates for DON range from 0.066 to $0.200 \mathrm{~d}^{-1}$ with a mean of $0.12 \mathrm{~d}^{-1}$.. The solubilization rate of the large and small carbon detritus is set to $s_{S D e t C}=s_{L D e t C}=0.08 \mathrm{~d}^{-1}$. The higher rate chosen for the nitrogen detritus solubilization is $s_{L \operatorname{DetN}}=s_{S \operatorname{DetN}}=0.11 \mathrm{~d}^{-1}$ consistent with the carbon detritus specific respiration rate on diatom aggregates of $0.083 \pm 0.034 \mathrm{~d}^{-1}$ (Ploug and Grossart, 2000). The fractions of semi-labile DON and DOC cell-contents $\left(\delta_{N}\right.$ and $\left.\delta_{C}\right)$ described above are used to quantify the release of semi-labile DOM by solubilization. The labile DOM generated by solubilization (directed to the ammonium and DIC pools) uses the complementary fractions $\left(1-\delta_{N}\right)$ and $\left(1-\delta_{C}\right)$.

\section{Mineralization of semi-labile DOC and DON}

Since the photo-oxidation process is likely to impact refractory DOC, it is not included in the model. Hopkinson et al. (2002) estimated rates for DOC and DON mineralization by bacteria at $19-20^{\circ} \mathrm{C}$ in the MAB. The mean DON degradation rate measured (see Table 4 in Hopkinson et al. 2002) with 
half-life values comprised between 4 days $\left(0.173 \mathrm{~d}^{-1}\right)$ and 365 days $\left(0.0019 \mathrm{~d}^{-1}\right)$ is $0.073 \pm 0.043 \mathrm{~d}^{-1}$ with a corresponding value for DOC of $0.055 \pm 0.057 \mathrm{~d}^{-1}$. In a recent six-month degradation experiment at $19-20^{\circ} \mathrm{C}$ with DOM collected in the MAB, rates of DOC mineralization are between $0.015 \mathrm{~d}^{-1}$ and $0.043 \mathrm{~d}^{-1}$ (Russ and Mannino, in prep). The values proposed here are $0.029 \mathrm{~d}^{-1}\left(\mathrm{t}_{1 / 2}=\right.$ $24 \mathrm{~d})$ for the semi-labile DOC and $0.060 \mathrm{~d}^{-1}\left(\mathrm{t}_{1 / 2}=12 \mathrm{~d}\right)$ for the semi-labile DON at $19-20^{\circ} \mathrm{C}$. Since temperature dependence is likely to occur with a $\mathrm{Q}_{10}=2$ (Pomeroy et al., 1991), the degradation rate has the following formulation:

Mineralization rate $\left[d^{-1}\right]=a_{0} e^{0.07 T}$

where $a_{0}=a_{C 0}=0.00767 \mathrm{~d}^{-1}$ for carbon, $a_{0}=a_{N 0}=0.0153 \mathrm{~d}^{-1}$ for nitrogen semi-labile DOM and $T$ is the temperature in ${ }^{\circ} \mathrm{C}$. Consequently for the semi-labile DOC, the degradation rate ranges between $0.0088 \mathrm{~d}^{-1}$ at $2^{\circ} \mathrm{C}$ to $0.0545 \mathrm{~d}^{-1}$ at $28^{\circ} \mathrm{C}$ and between $0.0176 \mathrm{~d}^{-1}$ at $2^{\circ} \mathrm{C}$ to $0.1086 \mathrm{~d}^{-1}$ at $28^{\circ} \mathrm{C}$ for the semi-labile DON. Although bacteria are involved in DOM degradation, bacteria are not explicitly included in the model to avoid the multiplicity of parameters that cannot be calibrated using our dataset. However, bacterial processes such as organic matter mineralization and solubilization of POM are included in the model with a $\mathrm{Q}_{10}$ temperature formulation.

\subsection{Other modifications to the model}

An additional light attenuation coefficient to account for colored dissolved organic matter (CDOM) was added to the water and chlorophyll attenuation in response to an overestimated euphotic depth simulated by the model in the MAB compared to observations. The light attenuation formulation for CDOM absorption correlated to salinity was implemented in agreement with the combined CDOM plus detritus absorption measurements at $443 \mathrm{~nm}\left(\mathrm{a}_{\mathrm{CDM}}(443)\right.$, Magnuson et al., 2004) in estuaries (Chesapeake Bay: $0.368 \pm 0.076 \mathrm{~m}^{-1}$ in the mid-Bay for a salinity of $12.9 \pm 3.2 \mathrm{psu}$, $0.284 \pm 0.090 \mathrm{~m}^{-1}$ in the lower Bay for a salinity of $\left.20.8 \pm 4.9 \mathrm{psu}\right)$, on the shelf $\left(0.168 \pm 0.057 \mathrm{~m}^{-1}\right.$ in the inshore MAB and $0.070 \pm 0.035 \mathrm{~m}^{-1}$ in the offshore MAB) and in oligotrophic waters $\left(0.010 \mathrm{~d}^{-1}\right.$ at the BATS station). The formulation used is (with salinity in psu):

$K_{C D O M}=0.5329-0.02669 *$ salinity $+0.0003395 *(\text { salinity })^{2}$

It is slightly lower $\left(\sim 0.1 \mathrm{~m}^{-1}\right.$ for salinity lower than $\left.30 \mathrm{psu}\right)$ than the observed $\mathrm{a}_{\mathrm{CDM}}(443)$ to account for a lower absorption of the PAR in the entire visible spectrum than in the blue $(443 \mathrm{~nm})$.

In the present model version, the zooplankton products (dead zooplankton and fecal pellets) and the aggregates of dead phytoplankton cells with small detritus are directed to the large detritus compartments instead of the slow-sinking small detritus compartments in Fennel et al. (2006). As a result in the water column, the small detritus compartments (SDet $N$ and $S \operatorname{Det} C$ ) are only fed by the dead, non-aggregated, phytoplankton cells and the large detritus compartments (LDet $N$ and $L D e t C$ ) include the aggregates of dead phytoplankton cells with the small detritus and the zooplankton products.

In order to explore the high POM burial of the U.S. northeastern continental shelf (Thomas et al., 2002) and to compare it with the horizontal export of DOM to the open ocean, a parameterization of POM resuspension and burial was added to the model's bottom boundary formulation. The resuspension rate of the POM flux reaching the seabed is a function of the bottom friction velocity. 
The resuspended fraction of POM is thus largely dependent on the local near bottom current velocity that is driven by the general circulation and tides on the continental shelf and by wind events in shallow waters. The remaining fraction of PON and POC accumulates and is buried in the sediment assuming that the burial efficiency of the particulate organic carbon is proportional to the vertical flux of POC reaching the seabed (Henrichs and Reeburgh, 1987). The POM resuspension and burial processes are fully described in the Appendix.

\subsection{Initial and boundary conditions}

Initial and boundary conditions for nitrate were derived using polynomial approximations that predict nitrate concentration from temperature using the NODC World Ocean Database 2001 (Fennel et al., 2006). The semi-labile DOC and DON boundary conditions are constant and set to $1.0 \mathrm{mmol} \mathrm{m}^{-3}$ and $0.15 \mathrm{mmol} \mathrm{m}^{-3}$ respectively. This approximation does not affect the MAB area because it is far enough from the boundary limits of NENA (Figure 1) to lose its memory (the time required to transport water masses from the boundary limit to the MAB is lower than the semi-labile DOM halftime). The same reasoning was applied to all other biological state variables with boundary conditions set to small background values. Monthly climatology for river flow, nitrate, and ammonium were derived from the U.S. Geological Survey monitoring database. The MAB receives a large supply of freshwater from the Hudson, Delaware and Chesapeake estuaries that carries high loads of DOC. Much of this DOC is believed to be of terrestrial origin, consisting of mostly refractory organic matter that can be transported across the shelf and into the open ocean (Aluwihare et al., 2002; Bauer, 2002). Although the semi-labile fraction is believed to be small, the main input of freshly produced DOM to the MAB is from production within the estuaries. Since the boundary conditions for the Chesapeake Bay and Delaware Bay are located in the mid and upper bay respectively, a polynomial fit is applied to the DOC data available in these areas from the Chesapeake Bay Program database (http://www.chesapeakebay.net/wquality.htm) and other sources (Jon Sharp, pers. comm.). A dampened seasonal pattern is emphasized with a minimum DOC value in March and a maximum value in early October with a mean of $297 \pm 14 \mathrm{mmol} \mathrm{m}^{-3}$. A small fraction $(10 \%)$ represents the semi-labile DOC and is used as a boundary condition for rivers. A Redfield C to $\mathrm{N}$ ratio, which approximately characterizes freshly produced DOM (i.e. the semi-labile fraction), is used to derive the semi-labile DON boundary condition for rivers. The river boundary condition for phytoplankton biomass and chlorophyll is set to background values of $1.8 \mathrm{mmol} \mathrm{N} \mathrm{m}^{-3}$ and $6.0 \mathrm{mg} \mathrm{Chl} \mathrm{m}{ }^{-3}$ respectively.

\section{Model results}

A spin up of seven months is conducted on the NENA domain to initialize the biogeochemical model (June 2003) for the year 2004. The results of twin simulations -with and without the DOM are discussed in the following subsections.

\subsection{Vertical and seasonal distribution of DOM}

A station chosen for the representation of the vertical and seasonal DOM processes from the southern MAB shelf is detailed in this section (station 3, see location in Figure 1) and compared to results in the central MAB and Georges Bank areas. As revealed by the simulation, station 3 is located in a region of marine production and export of DOC. The water depth at that station is only $46 \mathrm{~m}$, but this area is located near the shelf break at the vicinity of the Gulf Stream. The annual primary production at this site, $251 \mathrm{~g} \mathrm{C} \mathrm{m}^{-2} \mathrm{yr}^{-1}$, is characterized by a nitrate-sustained production at the subsurface in summer (Figure 5a and 5b). A nitrate concentration of $5 \mathrm{mmol} \mathrm{m}^{-3}$ is encountered 
at the depth of the $10 \%$ isolume during that period following an intrusion of the Gulf Stream as suggested by Schollaert et al. (2003) and observed in July 1996 (Redalje et al., 2002). The most important period of nutrient uptake, with values up to $0.8 \mathrm{mmol} \mathrm{NO}_{3} \mathrm{~m}^{-3} \mathrm{~d}^{-1}$ and $0.5 \mathrm{mmol} \mathrm{NH}_{4} \mathrm{~m}^{-3}$ $\mathrm{d}^{-1}$ (Figure 5a), occurs during summer between the mixed layer depth and the depth of the $10 \%$ isolume. The annual new production is $46 \%$ of the nutrient-based production (nitrate and ammonium), compared to $36 \%$ at station 2 where the Gulf Stream has less influence and $41 \%$ at the well-mixed tidal-driven station 1 . The carbon excess uptake at station 3 of $30 \mathrm{~g} \mathrm{C} \mathrm{m}^{-2} \mathrm{yr}^{-1}$ represents $12 \%$ of total primary production ( $14 \%$ at station 2 and $6 \%$ at the nutrient-rich station 1$)$. This 'extra' carbon uptake occurs at a shallower depth than the nitrogen-based uptake, within the nutrientdepleted mixed layer and immediately below where the gradients of biomass and light intersect. The spring bloom arises in March and early April at station 3 (Figure 11a), in late March and April at station 2 and in May at station 3. Contrary to a traditional maximum of phytoplankton biomass in the mixed layer during the spring bloom (station 2), the maximum biomass at station 3 is located at the subsurface during summer in relation with the Gulf Stream intrusion.

The bulk of semi-labile DON is formed at the three stations during the bloom and post-bloom periods with a maximal content near the surface of $3 \mathrm{mmol} \mathrm{m}$. This value is in agreement with the seasonal increase observed by Hopkinson et al. (1997), from 2 to $5 \mathrm{mmol} \mathrm{m}^{-3}$ ). The semi-labile DOC pool at station 3 increases rapidly during the decay phase of the spring bloom with values up to $55 \mathrm{mmol} \mathrm{m}^{-3}$ (Figure 11b). This freshly produced DOC pool is sustained until the end of May in relation with a high subsurface phytoplankton biomass. The progressive decrease of the subsurface biomass in June and July leads to a decrease of the surface semi-labile DOC content from 40 to $15 \mathrm{mmol} \mathrm{m}^{-3}$. A second increase to $23 \mathrm{mmol} \mathrm{m}^{-3}$ is observed in August linked to a shallower stratification. A slight subsurface maximum of semi-labile DOC and DON is observed at station 2 in July and August (results not shown). Homogeneous profiles of DOM are found at station 1, which alternate with surface maxima in relation with periodic stratification events. Figure 10 shows the seasonal variability of the semi-labile DOC concentration at the surface in the MAB and Georges Bank. The highest values in the MAB occur in spring $\left.(\sim 65 \mathrm{mmol} \mathrm{m})^{-3}\right)$ and in summer in Georges Bank with highest value in the shallowest area (from 30 to $50 \mathrm{mmol} \mathrm{m}^{-3}$ ). The semi-labile DOC concentrations remain elevated in rivers, estuaries and plumes of the MAB with, however, lower values in autumn. The slope off the MAB and Georges Bank between 100 and $1000 \mathrm{~m}$ shows a local maximum concentration in spring correlated with high primary production levels.

The model exhibits a stable and lowest $\mathrm{C}$ to $\mathrm{N}$ ratio of DOM during the growing phase of the spring bloom and an increasing ratio during the stationary and decaying phase of the bloom. The increase of $\mathrm{C}$ to $\mathrm{N}$ ratio (atoms) of DOM during the post-bloom in spring is from 10.5 to14.5 at station 1, 12.5 to 21.5 at station 2 and from 12.5 to 18.5 at station 3 in agreement with previous measurements (between 10 and 25, Benner et al., 1992).

\subsection{Horizontal DOM distribution and model evaluation}

The general distribution of total DOC concentration in surface waters described by Vlahos et al. (2002) shows an increase from northeast to southwest, and from offshore to inshore. These gradients arise from the production and accumulation of total DOC concentration on the shelf as a result of primary production and river inputs to southwestward flowing water mass (Vlahos et al., 2002; Mannino et al. 2008). The validation of the modeled semi-labile DOC is complicated by the different quantity measured in the field which includes also the labile and refractory fractions. Furthermore 
due to the particularly coarse model resolution in the estuary areas, we have less confidence in the simulated estuarine production, which is mostly exported in the inner- and part of the mid-shelf. We focus here on the outer shelf and slope where the model is well adapted and the exchange with the open ocean is high. Vlahos et al. (2002) derived areas of DOC production in the MAB subtracting from the total measured DOC the "expected" DOC concentration based on conservative mixing (using salinity). The "excess" DOC derived outside of the river plumes, i.e. mainly in the outer-shelf and slope, is thus comparable to the simulated semi-labile DOC. Vlahos et al. (2002) found an excess DOC from 20 to $55 \mathrm{mmol} \mathrm{C} \mathrm{m}{ }^{-3}$ in the surface outer and slope waters of the southern MAB in March 1996 and April 1994. In August 1996, values range from 10-15 to 25-30 mmol C m${ }^{-3}$ in the same area. The DOC decomposition study of Hopkinson et al. (2002) for near-surface waters of the MAB demonstrated a degradable DOC pool of $18-40 \mathrm{mmol} \mathrm{C} \mathrm{m}^{-3}$ in March 1996 and 23$50 \mathrm{mmol} \mathrm{C} \mathrm{m}^{-3}$ in August 1996 with two DOC components with half-lives of 1-14 days and 8-147 days. Mannino et al. (2008) attributed a seasonal increase in DOC of 12 to $34 \mathrm{mmol} \mathrm{C} \mathrm{m}{ }^{-3}$ within the southern MAB between Spring and Summer of 2005 and 2006 to net ecosystem production (phytoplankton exudation, particle solubilization, grazing, etc.) of semi-labile DOC. The model ranges from 15 to $60 \mathrm{mmol} \mathrm{C} \mathrm{m}^{-3}$ in March-April and from 15 to $35 \mathrm{mmol} \mathrm{C} \mathrm{m}^{-3}$ in August. At Georges Bank, the DOC dynamics show no major accumulation in the surface water during spring (Figure 10) in agreement with the observation (Chen, 1996).

Figure 4 presents the comparison of the mean June 2004 surface chlorophyll concentration derived by the model and by the satellite sensor SeaWiFS in the MAB and Georges Bank regions. The simulated chlorophyll distribution agrees well with the satellite observations particularly at the enhanced concentration on Georges Bank due to the tidal mixing and permanent nutrient availability. The river plumes and inner shelves are also well reproduced, including in the Chesapeake Bay where Harding et al. (2005) showed that SeaWiFS overestimates in situ chlorophyll by approximately $100 \%$. A feature which is not observed by the satellite sensor but appears in the model and is well documented (Ryan et al., 1999) is the enhancement of surface chlorophyll at the shelf break of the MAB and southern Georges Bank from mid-April to late June. These higher chlorophyll concentrations corresponds to the transition period from well-mixed to stratified conditions and is sustained by the upwelled nitrate-rich waters of the geostrophic jet that flows along the shelf break and slope from Georges Bank to Cape Hatteras (Ryan et al., 1999; Figure 5a and 5e).

A novel plot for quantitatively evaluating and displaying the skill of coupled biological-physical models, called the target diagram, has been recently introduced (Joliff et al., 2007). In these diagrams, bias and centered-pattern RMS are normalized by the standard deviation of the observations and plotted on the $\mathrm{x}$ - and $\mathrm{y}$-axes, respectively. Because the sum of the squares of these two components of the RMS difference is equal to the square of the total RMS difference, the distance from the origin to each plot symbol represents total RMS error. Although centered-pattern RMS is inherently a positive quantity, in the target diagram the centered-pattern RMS is multiplied by the sign of the difference: standard deviation of observations - standard deviation of model. Thus symbols are plotted with positive $\mathrm{x}$-coordinates if the model overestimates the variability of the data, and with negative $x$-coordinates if the model underestimates the variability of the data. The circle representing total $\mathrm{RMS}$ difference $=1.0$ (i.e. total RMS equals the standard deviation of the 


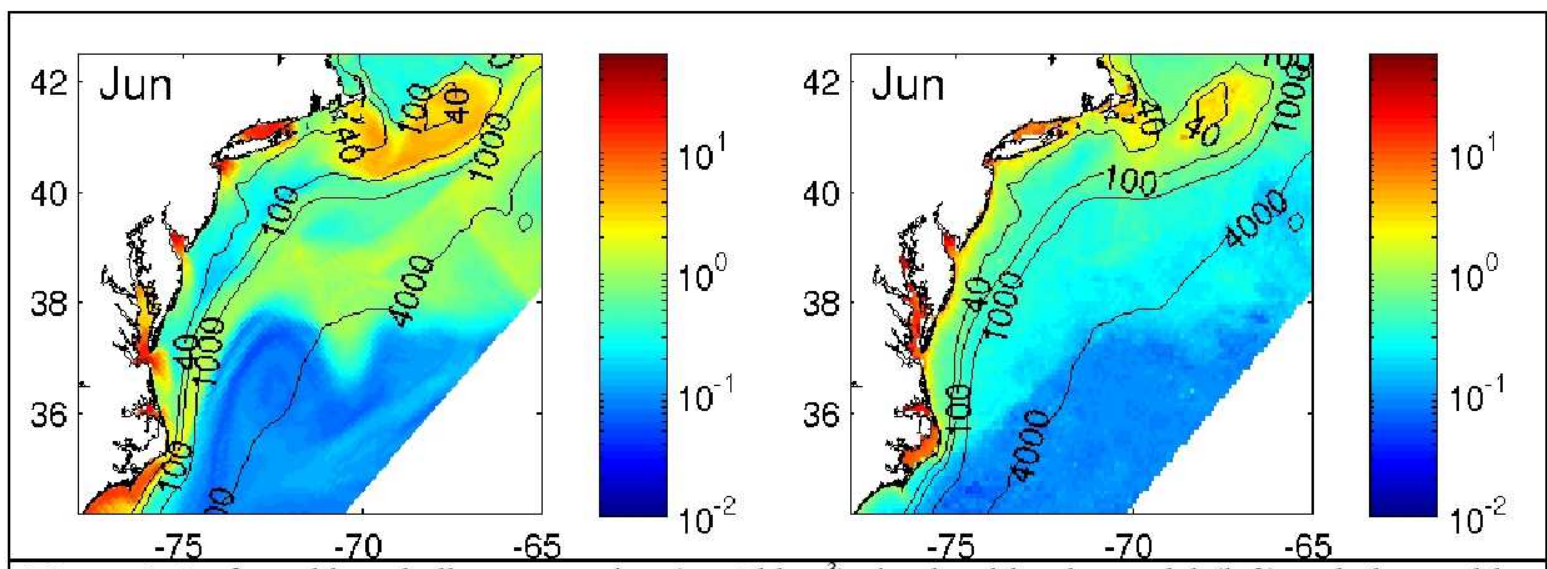

Figure 4. Surface chlorophyll concentration $\left(\mathrm{mg} \mathrm{Chl} \mathrm{m}^{-3}\right)$ simulated by the model (left) and observed by the satellite sensor SeaWiFS (right) using the algorithm OC4V4 for June 2004 in the MAB and Georges Bank regions. Isobaths are in meters.

observations) is typically superimposed on these diagrams for reference. By definition, model results falling within this circle reproduce observed quantities better than the mean of those observations. Target diagrams for both model runs (with and without DOM) are presented in Figure 6, and illustrate the skill of the models in reproducing the satellite monthly (2004) mean surface chlorophyll concentrations for the region encompassing the mid- and outer-shelf and slope of the MAB. This figure shows that the reference run generally (except February-April) underestimates the surface chlorophyll content, whereas the DOM run more often overestimates surface chlorophyll, especially in the spring (March and April). In the summer (June - August) the bias is nearly zero for the run with DOM., whereas the model results are negatively biased in the run without DOM. In these summer months both models underestimate the observed variability to the same degree. Both models also similarly overestimate the spatial variability of surface chlorophyll in February - May.

The organic carbon production in the MAB and Georges Bank regions (Figures $7 \mathrm{c}$ and $5 \mathrm{c}$ ) range between 100 and $300 \mathrm{~g} \mathrm{C} \mathrm{m}^{-2} \mathrm{yr}^{-1}$ in general agreement with previously published ranges (Falkowski et al. 1988 and Berger 1989: 120-300 $\mathrm{g} \mathrm{C} \mathrm{m}^{-2} \mathrm{yr}^{-1}$ ) with little alongshore variability on the central MAB (O'Reilly and Busch, 1984). However, this level of productivity is lower than the approach using mixed satellite and in situ profiles used by Mouw and Yoder (2005) with values of $320 \mathrm{~g} \mathrm{C} \mathrm{m}^{-}$ ${ }^{2} \mathrm{yr}^{-1}$ on the shelf, $304 \mathrm{~g} \mathrm{C} \mathrm{m}^{-2} \mathrm{yr}^{-1}$ on the shelf break and $411 \mathrm{~g} \mathrm{C} \mathrm{m}^{-2} \mathrm{yr}^{-1}$ on the slope of the northern MAB. Similarly higher productivity was estimated by O'Reilly et al. (1987) on Georges Bank with $455 \mathrm{~g} \mathrm{C} \mathrm{m}^{-2} \mathrm{yr}^{-1}$ on the shallowest sector, $310 \mathrm{~g} \mathrm{C} \mathrm{m}^{-2} \mathrm{yr}^{-1}$ between the 60 and $100 \mathrm{~m}$ isobaths and $265 \mathrm{~g} \mathrm{C} \mathrm{m}^{-2} \mathrm{yr}^{-1}$ between the 100 and $200 \mathrm{~m}$ isobaths. Compared to these higher estimates, the model estimates are too low by approximately $100 \mathrm{~g} \mathrm{C} \mathrm{m}^{-2} \mathrm{yr}^{-1}$.

The seasonal variability of simulated primary production on Georges Bank (Figure 8a) in May to September are in agreement with measurements (slightly above $1 \mathrm{~g} \mathrm{C} \mathrm{m}^{-2} \mathrm{~d}^{-1}$. O'Reilly et al., 1987), but the December to March levels of productivity of 0.01 to $0.10 \mathrm{~g} \mathrm{C} \mathrm{m}^{-2} \mathrm{~d}^{-1}$ in the model are significantly lower than observations $\left(0.2\right.$ to $\left.0.6 \mathrm{~g} \mathrm{C} \mathrm{m}^{-2} \mathrm{~d}^{-1}\right)$. The lack of a low-light sensitive phytoplankton group in the model is believed to be the cause of the winter underestimation of productivity. The percentage of extracellular release (PER) shown on Figure 8 is in agreement with the measurements of O'Reilly et al. (1987) between $14 \%$ in the shallow water ( 8 to $23 \%$ at station 1 ) and $21 \%$ over the slope of Georges Bank. Daily primary production levels simulated at station 2 


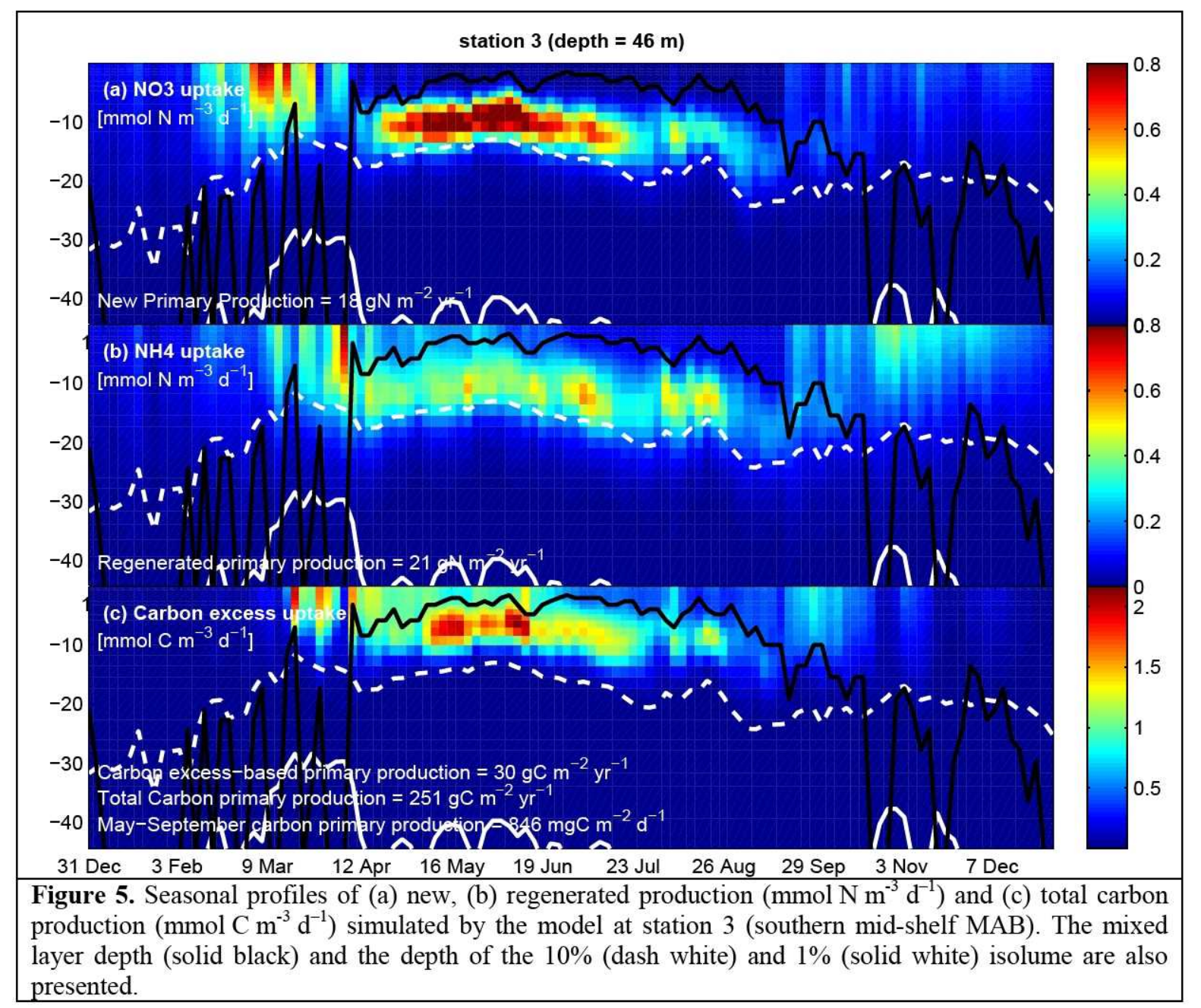

(Figure 8b) are also in agreement with the measurement of the SEEP-I experiment in 1984 with $0.60 \mathrm{~g} \mathrm{C} \mathrm{m}^{-2} \mathrm{~d}^{-1}$ in March and $1.33 \mathrm{~g} \mathrm{C} \mathrm{m}^{-2} \mathrm{~d}^{-1}$ in April (Falkowski et al., 1988). The inner shelf north and south of the Delaware Bay show a much stronger underestimation of productivity in the model $\left(100 \mathrm{~g} \mathrm{C} \mathrm{m}^{-2} \mathrm{yr}^{-1}\right)$ than the observation $\left(505 \mathrm{~g} \mathrm{C} \mathrm{m}^{-2} \mathrm{yr}^{-1}\right.$, O'Reilly et al., 1987). In that particular area, the phytoplankton is nitrogen-limited and the lack of sediment erosion by waves and POM resuspension is believed to cause such discrepancy. The levels of productivity provided by the model in the southern MAB shelf between the Chesapeake Bay mouth and Cape Hatteras (0.5$1.0 \mathrm{~g} \mathrm{C} \mathrm{m}^{-2} \mathrm{~d}^{-1}$ in March and July) are in the range of field data $\left(0.5-1.0 \mathrm{~g} \mathrm{C} \mathrm{m}^{-2} \mathrm{~d}^{-1}\right.$ in March and $0.5-2.0 \mathrm{~g} \mathrm{C} \mathrm{m}^{-2} \mathrm{~d}^{-1}$ in July, Verity et al., 2002). With the exception of the inner-shelf of the MAB, the productivity is thus well reproduced for the spring-summer-autumn period when the main DOC production events occur. POC deposition at the seabed was fairly well represented in the MAB shelf and slope. The POC deposition rates on the shelf off Delaware Bay and Chesapeake Bay are 2.7 and $2.1 \mathrm{~mol} \mathrm{C} \mathrm{m}^{-2} \mathrm{yr}^{-1}$, respectively, (Biscaye et al., 1994) in agreement with the model which ranges from 1.0 to 2.5 and from 1.0 to $4.0 \mathrm{~mol} \mathrm{C} \mathrm{m}^{-2} \mathrm{yr}^{-1}$, respectively (result not shown). The model, however, does not reproduce the POC deposition on the slope, with an underestimation factor of $\sim 10$ compared to field measurements (4.6 to $13.1 \mathrm{~mol} \mathrm{C} \mathrm{m}^{-2} \mathrm{yr}^{-1}$ off Cape Hatteras and 1 to $2 \mathrm{~mol} \mathrm{C} \mathrm{m}^{-}$ ${ }^{2} \mathrm{yr}^{-1}$ on other slope areas of the MAB; Biscaye et al., 1994; Schaff et al., 1992; Thomas et al., 2002). This suggests that the sinking velocity of the large detritus is too low or a third 'very large' 
detritus pool with sinking velocities of $100 \mathrm{~m} \mathrm{~d}^{-1}$ (Walsh, 1994) is lacking in the model to reproduce the POC deposition and burial on the slope.

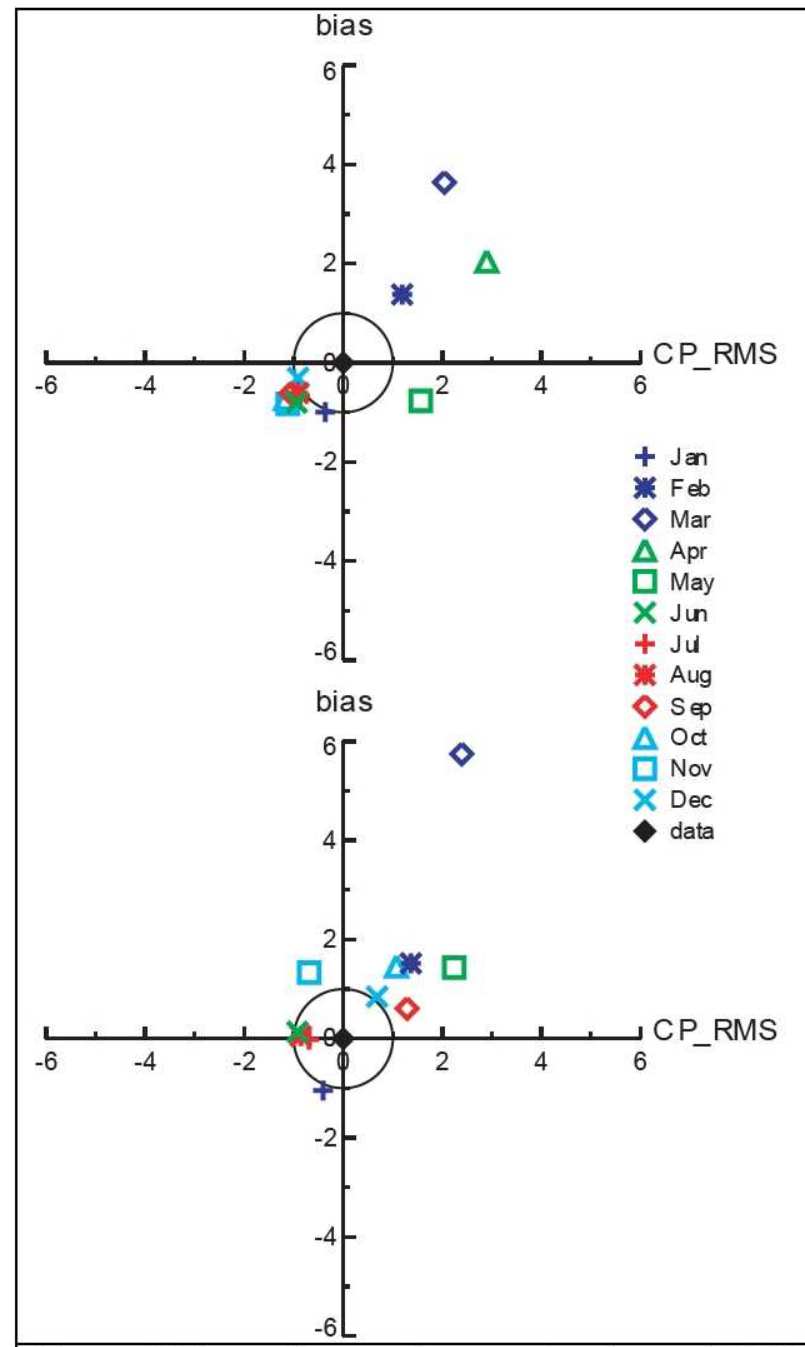

Figure 6. Target diagram (representing the total RMS difference, see text for details) of the monthly mean surface chlorophyll concentration between the model estimate and derived from satellite (SeaWiFS sensor) for the reference run (upper) and the run including DOM (lower). The area included in this evaluation comprises the Mid- and Outer-shelf and the slope of the MAB.
However, the focus in the present study is on the shelf burial of POC in comparison with the horizontal DOC export. Contrary to the POC deposition, the POC burial on the shelf is not well documented. Although the burial is probably slightly underestimated, consistent with a moderate underestimation of the primary production, we believe the model estimate of POC burial (Figure $9 \mathrm{~b})$ is realistic since the POC deposition rate agrees with field measurements and the simulated POC burial on the shelf is globally higher (from 1.5 to $\left.4.1 \mathrm{~mol} \mathrm{C} \mathrm{m}^{-2} \mathrm{yr}^{-1}\right)$ than the field estimates on the slope (1 to $2 \mathrm{~mol} \mathrm{C} \mathrm{m}^{-2} \mathrm{yr}^{-1}$ ).

\subsection{Semi-labile DOC export to the open ocean and POC burial}

The annual mean of horizontal divergence of semilabile DOC integrated over the water column (Figure 9a) shows specific areas of production and export (negative values) and areas of import (positive values) for both the shelf and the open ocean. Areas of high primary production are identified as regions of significant export of semilabile DOC. The DOC release in Georges Bank and the shelf south of Cape Cod is mainly exported in the central MAB shelf. The DOC released on the southern outer-shelf and slope of the MAB and off Cape Hatteras is exported to the adjacent deeper ocean. Both areas of export and import show an annual flux on the order of $1 \mathrm{~mol} \mathrm{C} \mathrm{m}^{-2} \mathrm{yr}^{-1}$.

The maxima in POC burial (Figure 9b) occur on the inner-shelf south of the dominant simulated rivers and estuaries (from North to South: the Connecticut, Housatonic and Hudson Rivers, the

Delaware and Chesapeake Bay, the Roanoke River, Figure 1). The productivity level and the water depth are the primary factors that determine the flux of organic matter near the seabed. The bottom friction then controls the POM deposition and the POM flux at the seabed, which regulate the burial through the burial efficiency. The river-influenced areas of the inner-shelf show a POC burial from 1.5 up to $4 \mathrm{~mol} \mathrm{C} \mathrm{m}^{-2} \mathrm{yr}^{-1}$. Except for the region south of Cape Cod and Georges Bank where the tidal-induced bottom friction prevents deposition, the rest of the shelf shows decreasing values of POC burial from inshore to offshore, with a flux of about 0.5 to $1 \mathrm{~mol} \mathrm{C} \mathrm{m}^{-2} \mathrm{yr}^{-1}$ following the $40 \mathrm{~m}$ isobath. For water depth greater than $100 \mathrm{~m}$ in the MAB, the POC is entirely mineralized in the 


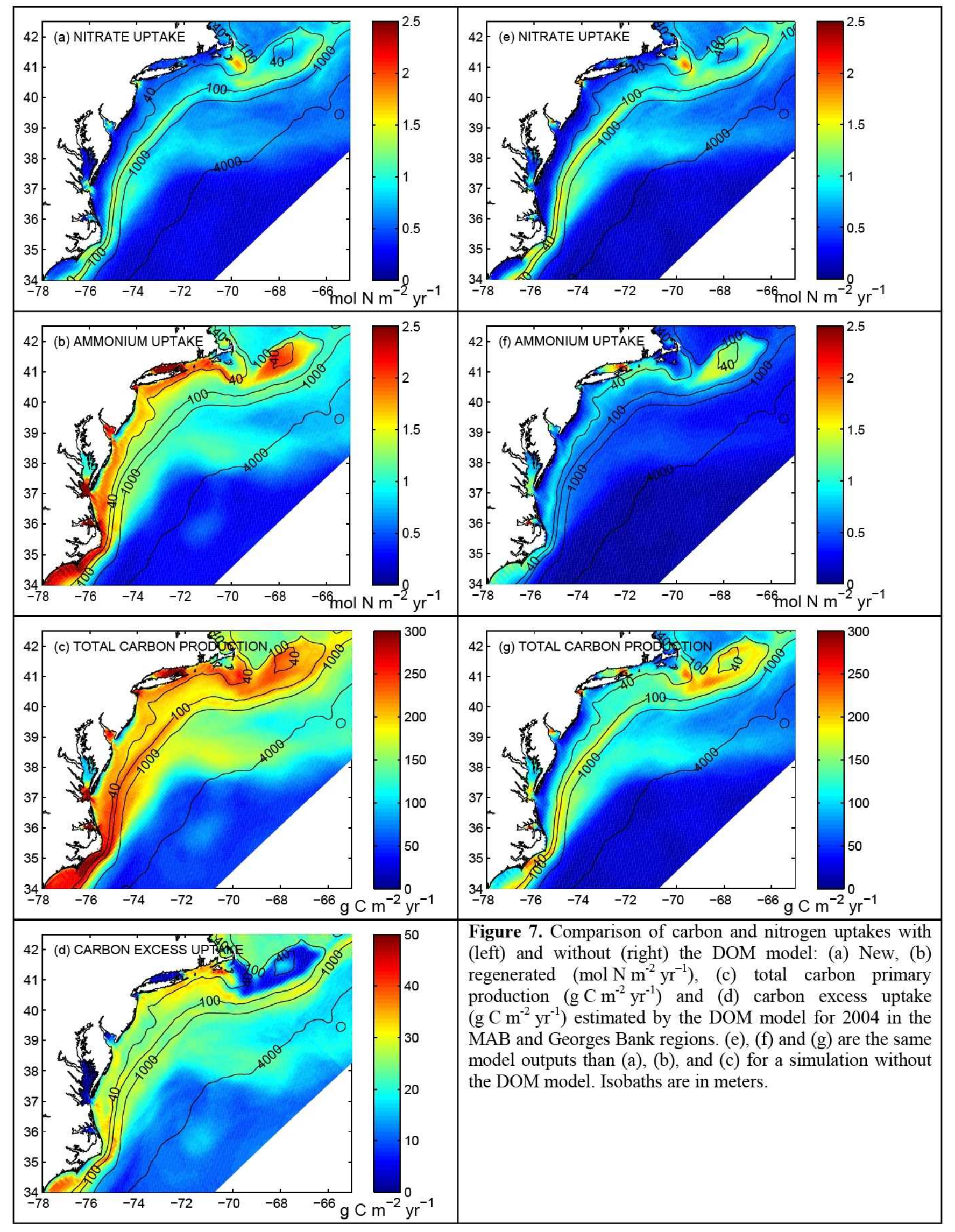


water column. The burial of PON has the same geographical distribution as POC with a $\mathrm{C}$ to $\mathrm{N}$ ratio of 9.3 (see Appendix).

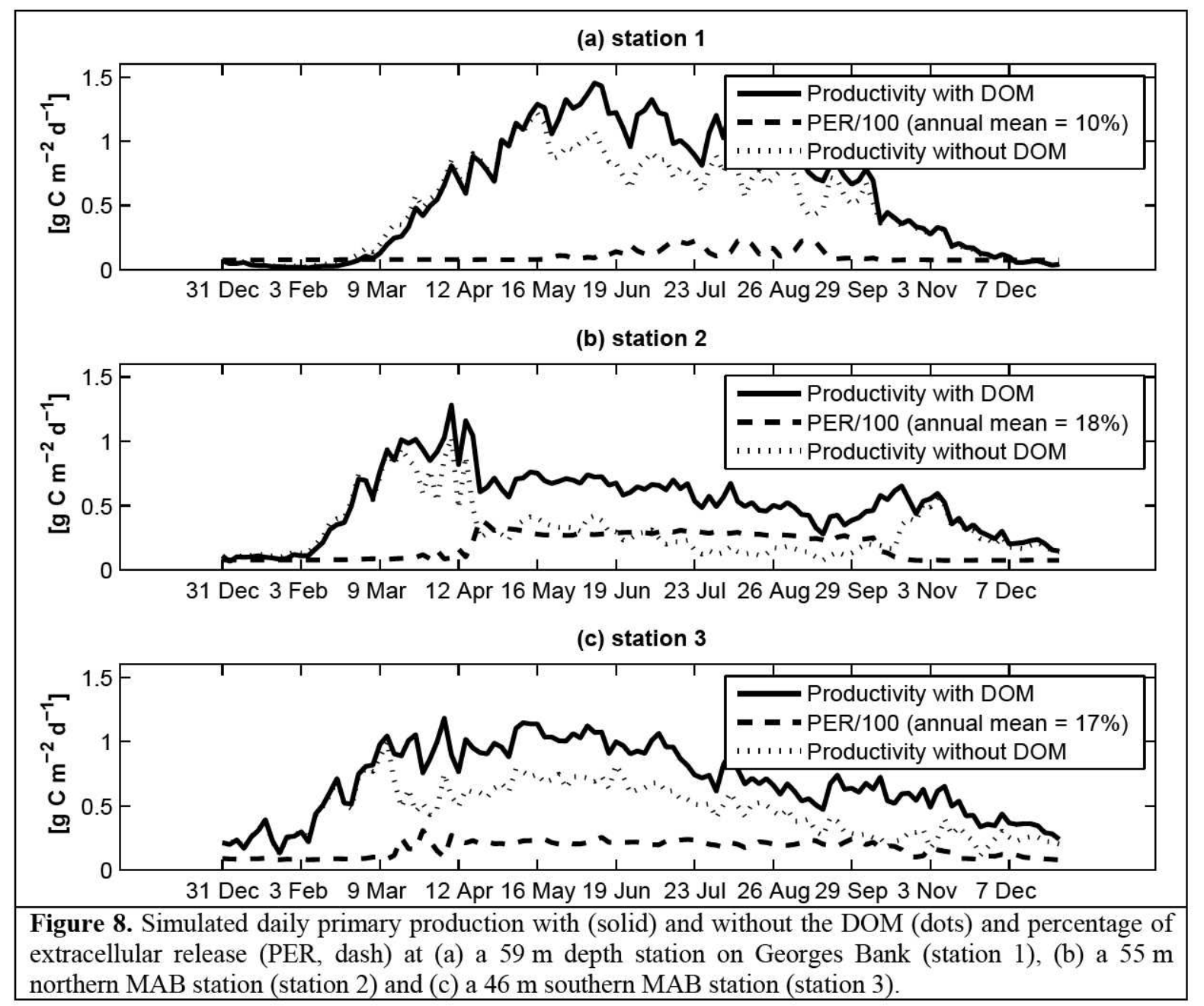

\section{Discussion}

\subsection{Impacts of the DOM on the ecosystem model}

In the simulation without the DOM, the POM pools are directly remineralized to DIC and ammonium using the same rates as in Fennel et al. (2006), i.e. $0.03 \mathrm{~d}^{-1}$ for small detritus and $0.01 \mathrm{~d}^{-1}$ for large detritus. Otherwise, the parameterization is the same for both simulations. The main impact of the introduction of the DOM is a large increase of regenerated production from $30 \%$ at Georges Bank and shelf break, $50 \%$ over the slope and deep ocean, to $250-300 \%$ in the mid- and inner-shelf of the MAB (Figures $7 \mathrm{~b}$ and $7 \mathrm{f}$ ). In contrast, the nitrate uptake shows globally the same distribution and level. The total carbon production shows an increase of 0 to $60 \mathrm{~g} \mathrm{C} \mathrm{m}^{-2} \mathrm{yr}^{-1}$ in the open ocean and the deeper Georges Bank (between 40 and $100 \mathrm{~m}$, station 1), among which 0 to $20 \mathrm{~g} \mathrm{C} \mathrm{m}^{-2} \mathrm{yr}^{-1}$ is linked to the carbon excess uptake. The increase in productivity ranges from 60 to $90 \mathrm{~g} \mathrm{C} \mathrm{m}^{-2} \mathrm{yr}^{-1}$ in the outer-shelf and the major part of the slope and from 90 to $180 \mathrm{~g} \mathrm{C} \mathrm{m}^{-2} \mathrm{yr}^{-1}$ in the inner- and midshelf among which 20 to $35 \mathrm{~g} \mathrm{C} \mathrm{m}^{-2} \mathrm{yr}^{-1}$ is related to carbon excess uptake. This enhanced production is mainly ( 65 to $100 \%$ ) caused by the progressive mineralization of the semi-labile DON 

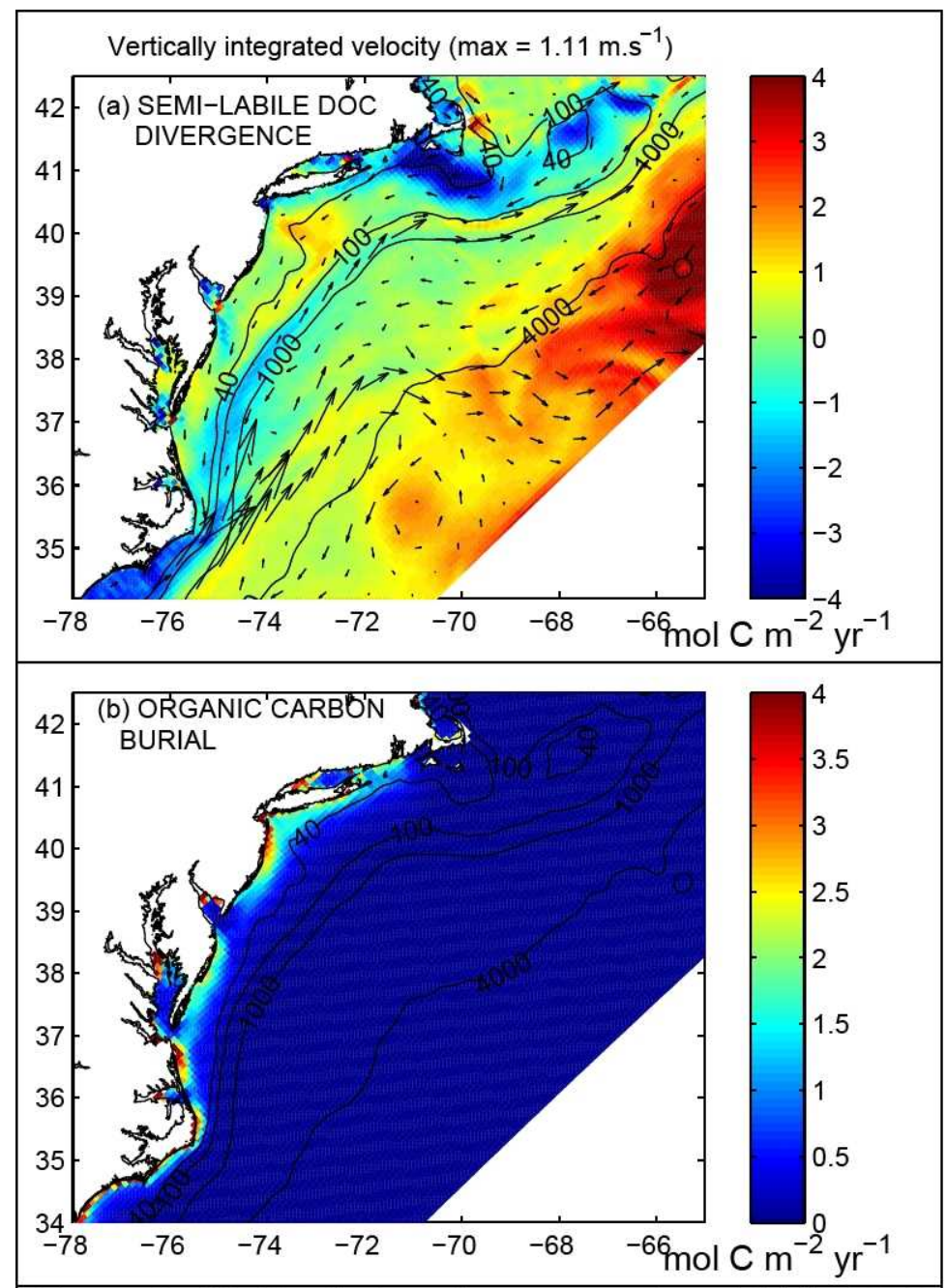

Figure 9. (a) Net horizontal transport of semi-labile DOC $\left(\mathrm{mol} \mathrm{C} \mathrm{m}{ }^{-2} \mathrm{yr}^{-1}\right)$ estimated by the model for the year 2004 in the $\mathrm{MAB}$ and Georges Bank regions: negative values are areas of production and export of semi-labile DOC and positive values are area of import. (b) Carbon burial $\left(\mathrm{mol} \mathrm{C} \mathrm{m} \mathrm{yr}^{-2}\right)$ for the same area and period. Isobaths are in meters. in surface waters in summer and autumn (Figure 11c). The productivity supported by DON during summer and autumn could explain the usual underestimation of models which do not include DON (e.g. Fennel 2006). Only 0 to $35 \%$ of this increase is related to the 'extra' production of carbohydrates depending on the level of nutrient depletion. The shelf area that shows the minimum increase in primary production between the two simulations occurs in the simulation without DOM in the Georges Bank area between the 40 and $100 \mathrm{~m}$ isobaths (Figure 8, station 1). In that area, the constant supply of nutrient by the tidal-induced mixing reduces the importance of DON as a source of nitrogen in the upper layer from mineralization. The phytoplankton biomass and chlorophyll levels are also dramatically lower without the DOM module, particularly in the MAB shelf and slope (Figure 6). This figure emphasizes accordingly a better estimate of the surface chlorophyll content in summer with the DOM components and higher levels in winter and autumn.

\subsection{The semi-labile DOM dynamics}

The most important contributor to the semi-labile DOC near the surface at station 3 is the phytoplankton exudation which occurs mainly within the mixed layer during the stationary and decaying phases of the bloom and between the mixed layer depth and the $10 \%$ isolume during summer (see Figure 5 and Figure 12a). Note that the contribution of the carbon excess-based release in summer occurs in the upper part of this subsurface layer where phytoplankton is nutrient-limited (Figure 5c) and the nutrientbased release in the deeper and light-limited part (Figures 5a and 5b). The other important contributor to DOC release is the POC solubilization which occurs deeper in the water column than the phytoplankton release. The integrated flux of DOC release by POC solubilization (Figure 12c) is, however, about three times greater than the release by exudation although it is more diffuse within the water column. A large release occurs after the spring bloom below the $10 \%$ isolume due to the aggregation into fast-sinking particles. During summer, the release of semi-labile DOC by solubilization increases substantially between the surface mixed-layer and the depth of the $10 \%$ isolume where the small, slow-sinking, detritus dominates. The next increase of semi-labile DOC release by solubilization in summer occurs near the seabed in correlation with the production of 


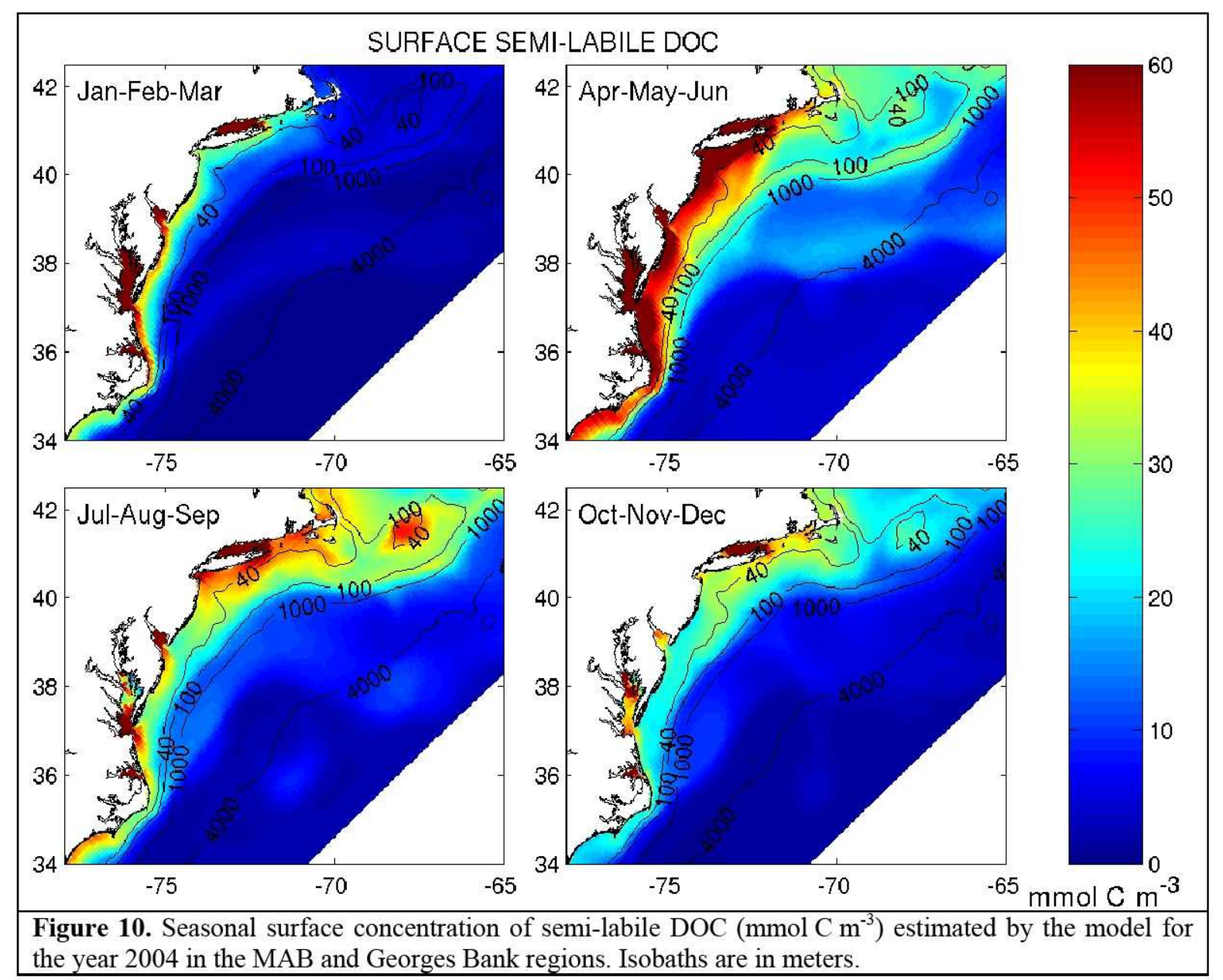

larger particles (fecal pellets) and the accumulation by POC resuspension. The smallest contributor to DOC release at station 3 is sloppy feeding by zooplankton (Figure 12b), which accounts for approximately $1 \%$ of the annual release, although it temporarily reaches $10 \%$ of the total DOC release. This simulated rate can reach $50 \%$ in highly productive areas such as the Chesapeake Bay mouth during a bloom in agreement with the field estimates of Møller et al. (2003).

Overall at station 3, the vertically integrated reservoir of semi-labile DOC is 1.5 times higher than the carbon detritus pool and twice the carbon standing stock of phytoplankton (Figure 12d). At station 1 and 2, the semi-labile DOC pool is twice the POC pool and four times the carbon phytoplankton pool. It represents therefore the largest freshly produced organic pool of carbon in the water column of the mid and outer shelf. It can be efficiently exported by horizontal transport (see next section) since this organic carbon is in the dissolved form and is slowly mineralized. Figure $12 \mathrm{~d}$ suggests that a large fraction of the carbon dioxide entering the shelf ocean is stored in semi-labile DOC since 12 to $14 \%$ of the $\mathrm{CO}_{2}$ flux is buried at stations 2 and 3 (less at station 1 where tidal mixing prevents from deposition).

\subsection{Carbon export}

The annual carbon dioxide air-sea flux simulated by the model is positive for the entire study area (such as at station 3, Figure 12d) except in the upper part of the Chesapeake Bay where a continuous 


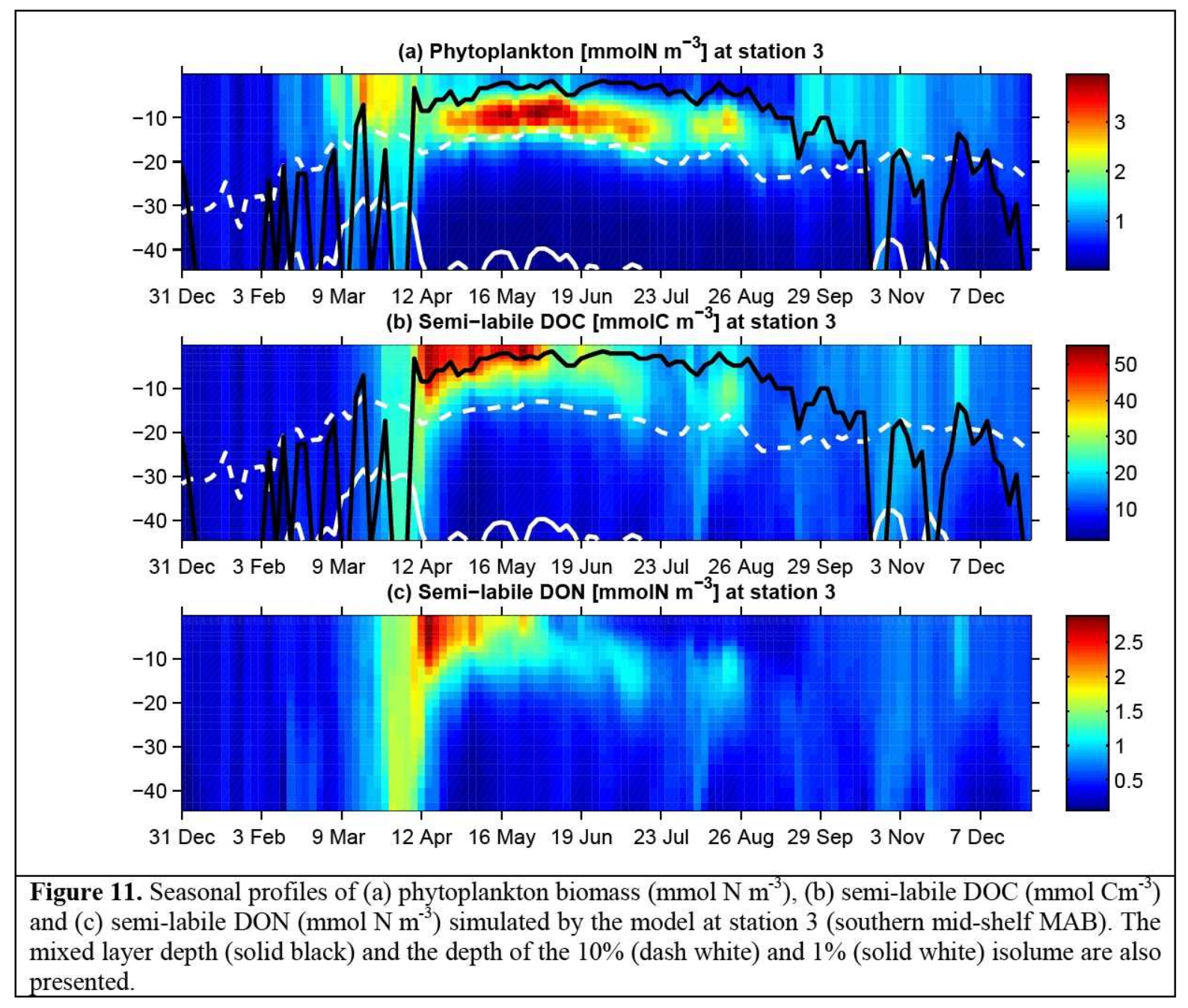

flow of terrestrial organic materials favors the mineralization and generates a source flux of dissolved $\mathrm{CO}_{2}$ to the atmosphere. The annual flux is from 0.5 to $2.0 \mathrm{~mol} \mathrm{C} \mathrm{m}^{-2} \mathrm{yr}^{-1}$ in the deep ocean and on the shelf except South of Cape Cod and Georges Bank where values range between 2 and $5 \mathrm{~mol} \mathrm{C} \mathrm{m}^{-2} \mathrm{yr}^{-1}$. This is in agreement with DeGrandpre et al. (2002) who estimated a net annual uptake of $\sim 1 \mathrm{~mol} \mathrm{~m}^{-2} \mathrm{yr}^{-1} \mathrm{CO}_{2}$ on the MAB. Since the carbon-rich DOM buildup contributes to $\mathrm{CO}_{2}$ drawdown seasonally (Sambrotto et al., 1993), the results suggest that a large amount of the carbon entering the surface ocean is temporarily stored in DOC.

Both degradation rates of the particulate and dissolved organic carbon (carbon detritus and DOC) are significantly lower than for the nitrogen detritus and DON leading to a lower regeneration rate for carbon than nitrogen. DOC and POC are consequently more efficiently exported through horizontal transport and sinking, respectively, than DON and PON.

The carbon export of POC from the shelf to the slope has been studied extensively (e.g. Biscaye and Anderson, 1994; Thomas et al., 2002) and was shown to be particularly important near Cape Hatteras where both the MAB (Mayer et al., 2002) and SAB production (Schaff et al., 1992) contribute to the shelf-slope carbon efflux due to the converging shelf circulation. The comparison presented in Figure 9 shows that POC is buried in the inner- and mid-shelf of the MAB at rates 


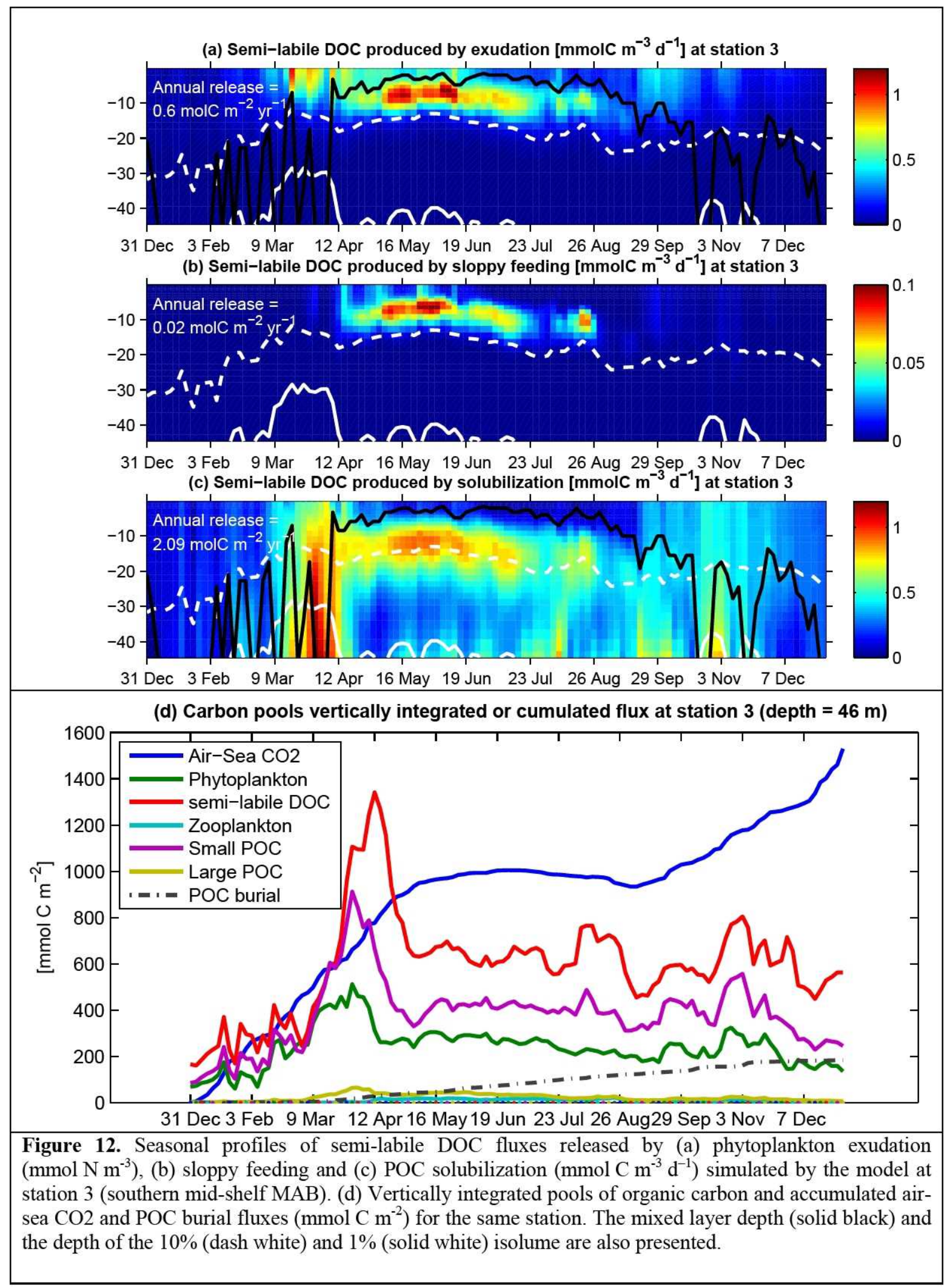

comparable to the export of seasonally produced DOC from the outer-shelf and slope to the open ocean. In contrast to the southern MAB, the DOC produced at Georges Bank and south of Cape Cod 
is mostly exported southward to the central MAB shelf between Long Island and Delaware Bay and does not contribute to a net export to the deep ocean.

\section{Conclusions}

The present study couples a circulation model to a biogeochemical model of carbon and nitrogen which includes the major DOM production processes to estimate (1) the role of DOM in the coastal ecosystem $\mathrm{C}$ and $\mathrm{N}$ cycling and (2) the relative importance of the export of freshly produced DOC to the open ocean compared to POC burial on the shelf. The carbohydrate production by phytoplankton, which occurs in nutrient-depleted and light-replete conditions, partially decouples the carbon and nitrogen primary production. The results show that DOM increases primary productivity by 60 to $180 \mathrm{~g} \mathrm{C} \mathrm{m}^{-2} \mathrm{yr}^{-1}$ in the $\mathrm{MAB}$, of which 65 to $100 \%$ is related to the ammonium release by DON mineralization in the upper layer and 0 to $35 \%$ to the 'extra' production of carbohydrates. Because DOM release by exudation and progressive mineralization occur near the surface, it is the most important process involved in this increase of primary productivity. However, in terms of flux, the annual release of semi-labile DOC by the deeper POC solubilization can be three times higher than the near-surface release by exudation. The seasonally produced DOC export from the shelf to the open ocean occurs mostly in the southern outer-shelf and slope of the MAB at a comparable rate ( $\sim 1$ to $2 \mathrm{~mol} \mathrm{~m}^{-2} \mathrm{yr}^{-1}$ ) to POC burial in the inner- and mid-shelf. Subsequent steps in model development will consider the inclusion of the refractory DOC (as a passive tracer), multiple phytoplankton and zooplankton functional groups, a diagenetic sub-model to simulate remineralization and burial in the sediment, a fast sinking detritus $\left(\sim 100 \mathrm{~m} \mathrm{~d}^{-1}\right)$ and a higher horizontal resolution in shallow areas. The model parameterization and evaluation will also be improved by using new products derived from satellite remote sensing of surface DOC and POC concentration. These refinements will allow for a more complete estimate of the carbon budget at the scale of the Eastern U.S. continental shelf and provide for a better understanding of the role of DOC in the dynamics of carbon cycling at the land-ocean interface.

\section{Acknowledgments}

This work was supported by a NASA postdoctoral associateship arranged by Dr. Paula Bontempi, the NASA Ocean Biology and Biogeochemistry Program Manager, in the frame of the NASA Interdisciplinary Science Project U.S. Eastern Continental Shelf Carbon Budget (USECoS, http://www.ccpo.odu.edu/Research/US-ECoS/). We wish to thank John O'Reilly, Cindy Lee, Eileen Hofmann, Ray Najjar and Dale Haidvogel for the constructive discussions and suggestions on the project and Rutgers University, Institute of Marine and Coastal Sciences, for supplying the computer resources. 


\section{Appendix}

\section{Parameter set}

See Tables A1, A2 and A3

\section{Equations of the state variables}

\section{Semi-labile DON and DOC}

The time rate of change of the semi-labile DON and DOC are:

$\partial \mathrm{DON} / \partial \mathrm{t}=$ Phytoplankton exudation + Sloppy feeding +

+ Solubilization small and large $\mathrm{N}$ detritus (semi-labile fraction)

- Remineralization semi-labile DON

$$
\begin{aligned}
\frac{\partial D O N}{\partial t} & =\varepsilon_{\mathrm{N}} \mu P h y+(1-\beta) Q_{D O N} \delta_{\mathrm{N}} g \text { Zoo }+ \\
\ldots & +\delta_{\mathrm{N}}\left(\mathrm{s}_{\mathrm{SDetN}} S \operatorname{Det} N+\mathrm{s}_{\mathrm{LDetN}} \operatorname{LDet} N\right)-a_{N 0} e^{0.07 T} D O N
\end{aligned}
$$

where $\mu$ is the phytoplankton growth rate.

$\partial \mathrm{DOC} / \partial \mathrm{t}=$ Phytoplankton exudation (nutrient-based and carbon excess-based)

+ Sloppy feeding + Solubilization small and large $\mathrm{C}$ detritus (semi-labile fraction)

- Remineralization semi-labile DOC

$$
\begin{aligned}
\frac{\partial D O C}{\partial t} & =C N_{P}\left(\varepsilon_{\mathrm{N}} \mu P h y+\sigma_{C} \gamma\left[\mu_{\max } L_{L}\left(1-L_{N}\right)\right] P h y+(1-\beta) Q_{D O C} \delta_{\mathrm{C}} g \text { Zoo }\right)+ \\
\ldots & \left.+\delta_{\mathrm{N}}\left(\mathrm{s}_{\mathrm{SDetN}} \operatorname{SDetC}+\mathrm{s}_{\mathrm{LDetN}} \operatorname{LDetC}\right)-a_{C 0} e^{0.07 T} D O C\right)
\end{aligned}
$$

where $L_{L}$ and $L_{N}$ are the non-dimensional terms that determine light- and nutrient-limitation, and $\mu_{\max }$ the maximum phytoplankton growth rate $\left(\mu=\mu_{\max } L_{L} L_{N}\right)$.

\section{Phytoplankton}

Two sink terms are added in the phytoplankton time rate of change: the exudation terms of semilabile and labile DON towards DON and ammonium respectively.

$\partial \mathrm{Phy} / \partial \mathrm{t}=$ Phytoplankton growth - Exudation of semi-labile DON

- Exudation of labile DON (to NH4) - Grazing - Phytoplankton mortality

- Aggregation with small N detritus - Sinking of living cells

$$
\frac{\partial P h y}{\partial t}=\mu P h y\left(1-\varepsilon_{N}-\omega_{N}\right)-g Z o o-m_{P} P h y-\tau(S D e t+P h y) P h y-w_{P} \frac{\partial P h y}{\partial z}
$$

where $m_{p}$ is the phytoplankton mortality rate, $\tau$ the aggregation parameter of the small detritus and $P h y$ (towards the large detritus pool) and $w_{P}$ is the sinking velocity of living phytoplankton cells. 
Phy is expressed in nitrogen unit using the constant $\mathrm{C}$ to $\mathrm{N}$ ratio $\left(C N_{p}\right)$ for accessing carbon units and therefore no equation is required for Phy expressed in carbon. A fraction $\left(\sigma_{C}\right)$ of the carbon excess uptake represents the semi-labile DOC exudation by phytoplankton and is directed towards the semilabile DOC.

\section{Chlorophyll}

The chlorophyll equation is modified accordingly to the changes of the phytoplankton equation:

$\partial \mathrm{Chl} / \partial \mathrm{t}=$ Chlorophyll production - Loss by exudation of semi-labile DON

- Loss by exudation of labile DON (to NH4) - Loss by grazing

- Loss by phytoplankton mortality - Loss by aggregation with small $\mathrm{N}$ detritus

- Loss by sinking of living cells

$$
\frac{\partial C h l}{\partial t}=\rho_{C h l} \mu C h l\left(1-\varepsilon_{N}-\omega_{N}\right)-g Z o o \frac{C h l}{P h y}-m_{P} C h l-\tau(S D e t N+P h y) C h l-w_{P} \frac{\partial C h l}{\partial z}
$$

where $\rho_{\text {chl }}$ is the fraction of phytoplankton growth devoted to the chlorophyll synthesis (Geider et al., 1997):

$\rho_{\text {chl }}=\theta_{\max } \mu \mathrm{Phy} / \alpha$ I Chl

where $\theta_{\max }$ is the maximum ratio of chlorophyll to phytoplankton biomass, $\alpha$ is the initial slope of the phytoplankton growth curve relative to light and $I$ the photosynthetically available radiation.

\section{Zooplankton}

The zooplankton, like the phytoplankton, is only expressed in nitrogen unit:

$\partial \mathrm{Zoo} / \partial \mathrm{t}=$ Fraction of grazing assimilated

- Excretion (basal metabolism and grazing dependent) - Mortality

$$
\frac{\partial Z o o}{\partial t}=g \beta Z o o-\left(1_{\mathrm{BM}}+1_{\mathrm{E}} \beta \frac{\mathrm{g}}{\mathrm{g}_{\max }}\right) Z o o-m_{Z} Z o o^{2}
$$

The remaining term $[(1-\beta) \mathrm{g}$ Zoo] is divided between the production of semi-labile and labile DON by sloppy feeding (towards semi-labile DON and DIC respectively) and the production of fecal pellets (towards the small $\mathrm{N}$ detritus pool).

The zooplankton equation expressed in carbon is:

$$
\left.\frac{\partial Z o o}{\partial t}\right|_{C}=C N_{P} g \beta Z o o-\mathrm{CN}_{\mathrm{Z}}\left[\left(1_{\mathrm{BM}}+1_{\mathrm{E}} \beta \frac{\mathrm{g}}{\mathrm{g}_{\max }}\right) Z o o-m_{Z} Z o o^{2}\right]-r_{C e x c} \mathrm{CN}_{\mathrm{Z}} Z o o
$$

where $r_{C e x c}$ is the rate of carbon excess respiration due to the $\mathrm{C}$ to $\mathrm{N}$ ratio difference between phytoplankton and zooplankton. The constant zooplankton $\mathrm{C}$ to $\mathrm{N}$ ratio $\left(C N_{Z}=5.0\right)$ leads to the formulation:

$C N_{Z}=\left(C N_{P} \beta g\right.$ Zoo $\left.-r_{C e x c} C N_{Z} Z o o\right) / \beta g Z o o$ 
Or

$r_{C e x c}=\beta g\left(C N_{P}-C N_{Z}\right) / C N_{Z}$

This excess of respired organic carbon is directed to DIC. It ensures the conservation of the zooplankton $\mathrm{C}$ to $\mathrm{N}$ ratio and therefore the zooplankton equation expressed in carbon is implicit.

DIC

The air-sea exchange of carbon dioxide is taken from Fennel et al. (in prep.).

$\partial \mathrm{DIC} / \partial \mathrm{t}=$ - Nutrient-based uptake by phytoplankton growth

- C excess-based semi-labile DOC exudation

+ Nutrient-based exudation of labile DOC

+ Labile DOC produced by sloppy feeding

+ Excretion (basal metabolism and grazing dependent)

+ Solubilization small and large detritus C (labile fraction)

+ Remineralization of semi-labile DOC

+ Air-sea CO2 flux

$$
\begin{aligned}
\frac{\partial D I C}{\partial t} & =C N_{P}\left(-\mu P h y-\gamma \sigma_{C} \mu_{\max } L_{L}\left(1-L_{N}\right) P h y+\omega_{C} \mu P h y+(1-\beta) Q_{D O C}\left(1-\delta_{C}\right) g Z o o\right)+ \\
\ldots & +C N_{Z}\left(l_{B M}+l_{E} \beta \frac{g}{g_{\max }}+r_{C e x c}\right) Z o o+S_{S D e t C} S D e t C+S_{L D e t C} L D e t C+a_{C 0} e^{0.07 T} D O C+ \\
& \ldots+\frac{v K_{C O 2}}{\Delta z} C O_{2, \text { sol }}\left(p C O_{2, a i r}-p C O_{2}\right)
\end{aligned}
$$

\section{Ammonium}

$\partial \mathrm{NH}_{4} / \partial \mathrm{t}=-$ Ammonium uptake by phytoplankton growth + Exudation of labile DON

+ Labile DON produced by sloppy feeding

+ Excretion (basal metabolism and grazing dependent)

+ Solubilization small and large detritus N (labile fraction)

+ Remineralization of semi-labile DON - Nitrification

$$
\begin{gathered}
\frac{\partial N H 4}{\partial t}=-\mu_{\max } L_{L} L_{N H 4} P h y+\omega_{N} \mu P h y+(1-\beta) Q_{D O N}\left(1-\delta_{N}\right) g Z o o+\left(l_{B M}+l_{E} \beta \frac{g}{g_{\max }}\right) Z o o+ \\
\ldots+\left(1-\delta_{N}\right)\left(S_{S D e t N} \operatorname{SDetN}+S_{L D e t N} L D e t N\right)+a_{N 0} e^{0.07 T} D O N-n N H 4
\end{gathered}
$$

where $l_{B M}$ and $l_{E}$ are the zooplankton excretion rates due to basal metabolism and assimilation intensity respectively, and $\mathrm{n}$ is the nitrification rate (same parameterization than in Fennel et al. (2006). $L_{L}$ is the non-dimensional light limitation and $\mathrm{L}_{\mathrm{NH} 4}$ is the nutrient limitation term for ammonium. 


\section{Nitrate}

$\partial \mathrm{NO}_{3} / \partial \mathrm{t}=$ - Nitrate uptake by phytoplankton growth + Nitrification

$\frac{\partial N O 3}{\partial t}=-\mu_{\max } L_{L} L_{N O 3} P h y+n N H 4$

where $\mathrm{L}_{\mathrm{NO} 3}$ is the nutrient limitation term for nitrate.

Detritus $N$

$\partial \mathrm{SDetN} / \partial \mathrm{t}=$ Phytoplankton mortality - Aggregation with living phytoplankton cells

- Small detritus N solubilization - Sinking of small detritus N

$\frac{\partial S \operatorname{Det} N}{\partial t}=m_{P} P h y-\tau(S \operatorname{Det} N+P h y) S \operatorname{Det} N-s_{\text {SDetN }} S \operatorname{Det} N-w_{S} \frac{\partial S \operatorname{Det} N}{\partial z}$

$\partial \mathrm{LDetN} / \partial \mathrm{t}=$ Fecal pellets production (nitrogen fraction) + Zooplankton mortality

+ Aggregation of small detritus (N) and phytoplankton cells

- Large detritus N solubilization - Sinking of large detritus $(\mathrm{N})$

$\frac{\partial L D e t N}{\partial t}=(1-\beta)\left(1-Q_{D O N}\right) g Z o o+m_{z} Z_{o o}^{2}+\tau(S \operatorname{Det} N+P h y)^{2}-s_{L D e t N} L D e t N-w_{L} \frac{\partial L D e t N}{\partial z}$

\section{Detritus $C$}

$\partial \mathrm{SDetC} / \partial \mathrm{t}=$ Phytoplankton mortality $(\mathrm{C})-$ Aggregation with living phytoplankton cells

- Small detritus C remineralization - Sinking of small detritus C

$\frac{\partial S \operatorname{Det} C}{\partial t}=C N_{P} m_{P} P h y-\tau\left(\operatorname{SDet} C+C N_{P} P h y\right) S \operatorname{Det} C-s_{S \operatorname{DetC}} S \operatorname{Det} C-w_{S} \frac{\partial S \operatorname{Det} C}{\partial z}$

$\partial \mathrm{POC}_{\mathrm{L}} / \partial \mathrm{t}=$ Fecal pellets production (carbon) + Zooplankton mortality $(\mathrm{C})$

+ Aggregation of small detritus (C) and phytoplankton cells (C)

- Large detritus C solubilization - Sinking of large detritus (C)

$$
\begin{aligned}
\frac{\partial L D e t C}{\partial t}= & C N_{P}(1-\beta)\left(1-Q_{D o C}\right) g Z o o+C N_{z} m_{z} Z o o^{2}+\tau\left(S \operatorname{Det} C+C N_{P} P h y\right)^{2}-s_{L D e t C} L D e t C+ \\
& \ldots-w_{L} \frac{\partial L D e t C}{\partial z}
\end{aligned}
$$

where $w_{S}$ and $w_{L}$ are the sinking velocities of small and large detritus respectively.

\section{Oxygen}

The oxygen equation taken from Fennel et al. (in prep.) is modified as the following: 
$\partial \mathrm{Ox} / \partial \mathrm{t}=$ Phytoplankton growth linked to $\mathrm{N}$ uptake

+ Phytoplankton growth linked to $\mathrm{C}$ excess uptake

- Labile DOM oxidation - Labile DOM oxidation from sloppy feeding

- Zooplankton excretion

+ Solubilization small and large POM (labile fraction) - DOM oxidation

- Nitrification +Air-sea flux

$$
\begin{aligned}
\frac{\partial O x}{\partial t} & =\left(L_{N O 3} r_{O 2: N O 3}+L_{N H 4} r_{O 2: N H 4}\right) \mu_{\max } L_{L} P h y+\sigma_{C} C N_{P} \mu_{\max } L_{L}\left(1-L_{N}\right) P h y+ \\
& \ldots-r_{O 2: N H 4}\left[\omega_{N} P h y+(1-\beta) Q_{D O N}\left(1-\delta_{C}\right) g Z o o+\left(l_{B M}+l_{E} \beta \frac{g}{g_{\max }}\right) Z o o+\right. \\
& \left.\ldots+\left(1-\delta_{N}\right)\left(s_{S D e t N} S D e t N+s_{L D e t N} L D e t N\right)+a_{N 0} e^{0.07 T} D O N\right]+ \\
& \ldots-2 n N H 4+\frac{v K_{O 2}}{\Delta z}\left(O x_{\text {sat }}-O x\right)
\end{aligned}
$$

where $\mathrm{r}_{\mathrm{O} 2: \mathrm{NO} 3}$ and $\mathrm{r}_{\mathrm{O} 2: \mathrm{NH} 4}$ are the $\mathrm{O}_{2}: \mathrm{N}$ ratio for nitrate and ammonium respectively, $\nu \mathrm{K}_{\mathrm{O} 2}$ is the gas exchange coefficient for oxygen, $\Delta \mathrm{z}$ is the thickness of the top box and $\mathrm{Ox}_{\text {sat }}$ is the saturation concentration of oxygen.

The oxygen produced by the synthesis of carbohydrates (carbon excess uptake) has a one to one mole ratio with DIC following the equation: $\mathrm{CO}_{2}+\mathrm{H}_{2} \mathrm{O}+$ energy $->\left(\mathrm{CH}_{2} \mathrm{O}\right)+\mathrm{O}_{2}$.

The oxygen uptake from the solubilization of POM (PON+POC) and the oxidation of DOM $(\mathrm{DON}+\mathrm{DOC})$ is approximated to the solubilization of detritus $\mathrm{N}$ and oxidation of $\mathrm{DON}$ with a $\mathrm{C}$ to $\mathrm{N}$ ratio of 6.6 .

\section{Bottom boundary condition}

In order to take into account the resuspension of detritus $\mathrm{C}$ near the seabed due to bottom friction, a fraction ( $\lambda_{\text {res, }}$, see next section) of the bottom carbon flux is resuspended and mineralized in the lower water column. The complementary fraction $\left(1-\lambda_{\text {res }}\right)$ is buried, the flux of buried carbon thus is:

$F_{\text {Cburied }}=B E_{C}\left(1-\lambda_{\text {res }}\right) F_{\text {Cbottom }}$

Where $B E_{C}$ is the burial efficiency (see next section) and $F_{C b o t t o m}$ is the detritus $C$ flux that reaches the bottom before resuspension:

$$
F_{\text {Cbottom }}=\left.C N_{P} w_{P} \frac{\partial P h y}{\partial z}\right|_{z=H}+\left.w_{S} \frac{\partial S \operatorname{Det} C}{\partial z}\right|_{z=H}+\left.w_{L} \frac{\partial L \operatorname{Det} C}{\partial z}\right|_{z=H}
$$

The POM which is not resuspended nor buried is mineralized and therefore the bottom boundary condition for carbon follows:

$\partial \mathrm{DIC} /\left.\partial \mathrm{t}\right|_{\mathrm{z}=\mathrm{H}}=$ mineralization of (resuspended bottom detritus $\mathrm{C}$

+ not resuspended nor buried bottom POC)

$$
\left.\frac{\partial D I C}{\partial t}\right|_{z=H}=F_{\text {Cbottom }}\left(\lambda_{\text {res }}+\left(1-\lambda_{\text {res }}\right)\left(1-B E_{C}\right)\right)
$$


For nitrogen, the same resuspension rate is applied $\left(\lambda_{\text {res }}\right)$ to the detritus $\mathrm{N}$ reaching the seabed. The remaining detritus $\mathrm{N}$ is subject to burial and denitrification following:

$$
\begin{aligned}
& F_{\text {Nresuspended }}=\lambda_{\text {res }} F_{\text {Nbottom }} \\
& F_{\text {Nburied }}=B E_{N}\left(1-\lambda_{\text {res }}\right) F_{\text {Nbottom }} \\
& F_{\text {Ndenitrified }}=\left(1-B E_{N}\right)\left(1-\lambda_{\text {res }}\right) F_{\text {Nbottom }}
\end{aligned}
$$

where $F_{\text {Nbottom }}$ is the flux of detritus in nitrogen that reaches the bottom before resuspension:

$$
F_{\text {Nbottom }}=\left.w_{P} \frac{\partial P h y}{\partial z}\right|_{z=H}+\left.w_{S} \frac{\partial S \operatorname{Det} N}{\partial z}\right|_{z=H}+\left.w_{L} \frac{\partial L \operatorname{Det} N}{\partial z}\right|_{z=H}
$$

The denitrification process is taken into account as it was shown to be significant in the MAB (Fennel et al., 2006). The stoichiometry calculation shows that the bottom boundary condition for ammonium is:

$$
\begin{aligned}
\partial \mathrm{NH}_{4} /\left.\partial \mathrm{t}\right|_{\mathrm{Z}=\mathrm{H}} & =\text { mineralization of (resuspended bottom detritus } \mathrm{N} \\
& + \text { not resuspended nor buried bottom detritus } \mathrm{N} \\
& + \text { not resuspended nor denitrified bottom detritus } \mathrm{N} \text { ) }
\end{aligned}
$$

$$
\begin{aligned}
& \left.\frac{\partial N H_{4}}{\partial t}\right|_{z=H}=F_{\text {Nresuspended }}+\frac{4}{16} F_{\text {Ndenitrified }} \\
& \left.\frac{\partial N H_{4}}{\partial t}\right|_{z=H}=\left(\lambda_{\text {res }}+\frac{4}{16}\left(1-\lambda_{\text {res }}\right)\left(1-B E_{N}\right)\right) F_{N b o t t o m}
\end{aligned}
$$

The total amount of nitrogen lost through burial and denitrification $\left(\mathrm{N}_{2}\right)$ is:

$$
\begin{aligned}
& F_{\text {Nlost }}=F_{\text {Nburied }}+\frac{12}{16} F_{\text {Ndenitrified }} \\
& F_{\text {Nlost }}=\frac{4}{16}\left(1-\lambda_{\text {res }}\right)\left(3+B E_{N}\right) F_{\text {Nbottom }}
\end{aligned}
$$

\section{The POM resuspension}

The resuspension is taken into account as a function of the friction velocity at the seabed $\left(U^{*}\right)$. The resuspension rate (\%) follows:

$\lambda_{\text {res }}=\frac{\left(U^{*}\right)^{2}}{\left(U_{d}^{*}\right)^{2}}$

where $U^{*}{ }_{d}$ is the critical friction velocity above which all organic matter is maintained in suspension $\left(U^{*}{ }_{d}=0.31 \mathrm{~cm} \cdot \mathrm{s}^{-1}\right.$, Peterson, 1999). The resuspended fraction of POC is thus largely dependent of 
the local near bottom current velocity which is driven by the general circulation and the tides on the continental shelf and also by wind events in shallow waters.

\section{The POM burial}

Thomas et al. (2002) measured and reviewed high rates of carbon burial along the continental shelf of the U.S. northeastern continental shelf. The carbon and nitrogen burial rates have been implemented to simulate the loss of material in the sediment.

A fraction (burial efficiency, $\mathrm{BE}_{\mathrm{C}}$ ) of the particulate organic carbon that reaches the seabed is buried following the empirical expression of Henrichs and Reeburgh, 1987:

$\log F_{c}=0.69 \log w+2.27$

and

$B E_{C}=w^{0.4} / 2.1$

where $F c$ is the organic carbon flux at the sediment surface $\left(\mathrm{gC} \mathrm{m}^{-2} \mathrm{y}^{-1}\right)$ and $w$ is the sediment accumulation rate $\left(\mathrm{cm} \mathrm{y}^{-1}\right)$. Resolving the system leads to the following formulation for $\mathrm{BE}_{\mathrm{C}}(\%)$ :

$B E_{C}=\frac{1}{2.1}\left[10^{\left(\frac{\log F c}{0.69}\right)-2.27}\right]^{0.4}$

This formulation matches the upper values of Thomas et al. (2002) who measured and reviewed burial efficiency values (in \% of organic carbon deposition): 10-20\% at the slope off Cape Cod (SEEP-I), $25-50 \%$ in the MAB (SEEP-II) $=25-50,3-40 \%$ at the slope off Cape Hatteras.

Gelinas et al. (2001) reviewed the $\mathrm{C}$ to $\mathrm{N}$ ratio of buried organic matter and reported values of 9-10 for the shelf and estuarine surface sediments and slightly lower in deeper waters. A value of $\mathrm{CN}_{\text {burial }}=9.3$ is used to estimate the flux of buried organic nitrogen in agreement with values measured in the sediment of the MAB shelf (Mayer et al., 2002; Mayer, unpub. data).

A maximum of $75 \%$ of carbon burial efficiency is applied as it corresponds to the maximum value measured:

$B E_{C}=\operatorname{MIN}\left\{\left[10\left(\log F_{C} / 0.69-2.27\right)\right] 0.4 / 2.1 ; 0.75\right\}$

For nitrogen burial, a similar expression of burial efficiency is used introducing a $\mathrm{CN}_{\text {burial }}$ ratio:

$B E_{N}=\operatorname{MIN}\left\{\left[10^{(\log (\text { CNburial } F N) / 0.69-2.27)}\right]^{0.4} / 2.1 ; 0.75\right\}$ 


\section{Tables}

Table 1: Summary of the terms involved in the uptake and exudation of nitrogen and carbon by phytoplankton. $P P_{L}$ is the nutrient-based primary production limited by light, $L_{N}$ is the nutrient limitation, $C N_{P}$ is the $\mathrm{C}$ to $\mathrm{N}$ ratio for phytoplankton and $\gamma$ the parameter of carbon excess-based DOC excretion by phytoplankton (see Table A1 for the definition of other parameters).

\begin{tabular}{|c|c|}
\hline Expression & Description \\
\hline$U_{N}=P P_{L} L_{N}$ & nitrogen-based primary production or uptake of nitrogen \\
\hline$U_{\text {nut.C }}=C N_{P} U_{N}$ & nutrient-based primary production in carbon \\
\hline$E_{l a b . N}=\omega_{N} U_{N}$ & exudation of labile DON (directed to ammonium) \\
\hline$E_{\text {lab.nut. } C}=C N_{P} \omega_{N} U_{N}$ & exudation of labile DOC (directed to DIC) \\
\hline$E_{\text {sem.N }}=\varepsilon_{N} U_{N}$ & exudation of semi-labile DON \\
\hline$E_{\text {sem.nut. }}=C N_{P} E_{\text {sem. } N}$ & nutrient-based exudation of semi-labile DOC \\
\hline$U_{\text {exc. } C}=C N_{P} \gamma P P_{L}\left(1-L_{N}\right)$ & carbon excess uptake by nutrient-stressed phytoplankton \\
\hline$E_{\text {lab.exc.C }}=\left(1-\sigma_{c}\right) U_{\text {exc.C }}$ & carbon excess-based exudation of labile DOC \\
\hline$E_{\text {sem.exc.C }}=\sigma_{c} U_{\text {exc.C }}$ & carbon excess-based exudation of semi-labile DOC \\
\hline
\end{tabular}

Table 2: Release DCAA flux from aggregates, carbon content of aggregates, fraction of nitrogen in released DCAA estimated by Smith et al., 1992), and DON release rates deduced from these data.

\begin{tabular}{|l|l|l|l|l|}
\hline $\begin{array}{l}\text { Aggregate } \\
\text { type (April } \\
1990)\end{array}$ & $\begin{array}{l}\text { DCAA release } \\
\left(\mu \mathrm{g} \cdot \mathrm{agg}^{-1} \cdot \mathrm{d}^{-1}\right) \\
(1)\end{array}$ & $\begin{array}{l}\text { Carbon content } \\
\left(\mu \mathrm{g} \mathrm{C} \cdot \mathrm{agg}^{-1}\right) \\
(2)\end{array}$ & $\begin{array}{l}\text { Nitrogen fraction in } \\
\text { released DCAA } \\
(\text { non-dimensional }) \\
(3)\end{array}$ & $\begin{array}{l}\text { DON release rate } \\
\left(\mathrm{gN}_{\left.\mathrm{DCAA} \cdot \mathrm{gN}_{\mathrm{agg}}{ }^{-1} \cdot \mathrm{d}^{-1}\right)}\right. \\
\text { assuming POC:PON=5 } \\
(1)^{*} 5.0^{*}(3) /(2)\end{array}$ \\
\hline $\begin{array}{l}\text { Larvacean } \\
\text { house }\end{array}$ & 0.936 & 3.5 & $23.3 / 155.2=0.150$ & 0.200 \\
\hline Diatom floc & 0.527 & 3.5 & $2.4 / 15.4=0.156$ & 0.117 \\
\hline $\begin{array}{l}\text { Larvacean } \\
\text { house }\end{array}$ & 0.478 & 3.2 & $8.0 / 53.6=0.149$ & 0.118 \\
\hline $\begin{array}{l}\text { Larvacean } \\
\text { house }\end{array}$ & 0.365 & 4.5 & $0.5 / 3.1=0.161$ & 0.066 \\
\hline
\end{tabular}


Table A1: DOM specific parameters

\begin{tabular}{|c|c|c|}
\hline Symbol & Value or range and Unit & Parameter or formulation \\
\hline$\omega_{N}$ & $\begin{array}{ll}0.03 \quad[\text { nondimensional }] & \text { of } \\
\text { primary production }(\mathrm{N}) & \end{array}$ & Labile DON exudation rate \\
\hline$\omega_{C}$ & $\begin{array}{l}0.03 \quad \text { [nondimensional] of } \\
\text { primary production }(\mathrm{C})\end{array}$ & Nutrient-based labile DOC exudation rate \\
\hline$\varepsilon_{N}$ & $\begin{array}{l}0.04 \text { [nondimensional] of } \mathrm{N} \\
\text { primary production }\end{array}$ & Exudation rate of phytoplankton semi-labile DON \\
\hline$\gamma$ & 0.20 [nondimensional] & Parameter of carbon excess-based DOC exudation \\
\hline$\sigma_{C}$ & 0.45 [nondimensional] & $\begin{array}{l}\text { Fraction of semi-labile DOC produced by the carbon } \\
\text { excess-based exudation }\end{array}$ \\
\hline$\delta_{N}$ & 0.30 [nondimensional] & $\begin{array}{l}\text { Fraction of semi-labile DON to total DON within the } \\
\text { phytoplankton cell }\end{array}$ \\
\hline$\delta_{C}$ & 0.55 [nondimensional] & $\begin{array}{l}\text { Fraction of semi-labile DOC to total DOC within the } \\
\text { phytoplankton cell }\end{array}$ \\
\hline$Q_{D O N}$ & $\begin{array}{l}0.0-0.71 \text { [nondimensional]: } \\
\text { function of the ratio } \\
\text { grazing:maximum grazing } \\
\left(\mathrm{g} / \mathrm{g}_{\max }\right)\end{array}$ & $\begin{array}{l}\text { Fraction of total DON to (DON+PON) within the } \\
\text { phytoplankton cell }\end{array}$ \\
\hline$Q_{D O C}$ & $\begin{array}{l}0.0-0.71 \text { [nondimensional]: } \\
\text { function of the ratio } \\
\text { grazing:maximum grazing } \\
\left(\mathrm{g} / \mathrm{g}_{\max }\right)\end{array}$ & $\begin{array}{l}\text { Fraction of total DOC to }(\mathrm{DOC}+\mathrm{POC}) \text { within the } \\
\text { phytoplankton cell }\end{array}$ \\
\hline$a_{N o}$ & $0.01530 \mathrm{~d}^{-1}$ & $\begin{array}{l}\text { Remineralization rate of semi-labile DON at } 0^{\circ} \mathrm{C}\left(\mathrm{a}_{\mathrm{NT}}\right. \\
\left.=\mathrm{a}_{\mathrm{N} 0} \mathrm{e}^{0.07 \mathrm{~T}} \text {, with } \mathrm{T} \text { in }{ }^{\circ} \mathrm{C}\right)\end{array}$ \\
\hline$a_{C O}$ & $0.00767 \mathrm{~d}^{-1}$ & $\begin{array}{l}\text { Remineralization rate of semi-labile DOC at } 0^{\circ} \mathrm{C}\left(\mathrm{a}_{\mathrm{CT}}\right. \\
\left.=\mathrm{a}_{\mathrm{C} 0} \mathrm{e}^{0.07 \mathrm{~T}} \text {, with } \mathrm{T} \text { in }{ }^{\circ} \mathrm{C}\right)\end{array}$ \\
\hline$s_{S D e t N}$ & $0.11 \mathrm{~d}^{-1}$ & Bacterial solubilization rate of small $\mathrm{N}$ detritus \\
\hline$s_{L D e t N}$ & $0.11 \mathrm{~d}^{-1}$ & Bacterial solubilization rate of large $\mathrm{N}$ detritus \\
\hline$s_{S D e t C}$ & $0.08 \mathrm{~d}^{-1}$ & Bacterial solubilization rate of small $\mathrm{C}$ detritus \\
\hline$S_{L D e t C}$ & $0.08 \mathrm{~d}^{-1}$ & Bacterial solubilization rate of large $\mathrm{C}$ detritus \\
\hline
\end{tabular}


Table A2: Modified parameterization from Fennel et al. (2006)

\begin{tabular}{|c|c|c|c|}
\hline Symbol & $\begin{array}{l}\text { New value or range, } \\
\text { and Unit }\end{array}$ & Former value & Parameter \\
\hline$\alpha^{\mathrm{a}}$ & $0.020(\mathrm{~W} \cdot \mathrm{m}-2)^{-1} \cdot \mathrm{d}^{-1}$ & $0.025(\mathrm{~W} \cdot \mathrm{m}-2)^{-1} \cdot \mathrm{d}^{-1}$ & Initial slope of the P-I curve \\
\hline$\mu_{\max }^{\mathrm{a}}$ & $1.6 \mathrm{~d}^{-1}$ & $\begin{array}{l}0.59 * 1.066^{\mathrm{T}} \text { ( } T \text { is the } \\
\text { temperature in }{ }^{\circ} \mathrm{C} \text {, } \\
\text { Eppley, 1972) }\end{array}$ & $\begin{array}{l}\text { Maximum growth rate of } \\
\text { phytoplankton }\end{array}$ \\
\hline$C N_{Z}{ }^{\mathrm{b}}$ & 5.0 [nondimensional] & 6.625 & Zooplankton $\mathrm{C}$ to $\mathrm{N}$ ratio \\
\hline$\beta^{\mathrm{b}}$ & $\begin{array}{ll}0.22-085 & \text { for } \\
\mathrm{g} / \mathrm{g}_{\max }=[1.0-0.0] & \\
{[\text { nondimensional }]} & \end{array}$ & 0.75 & $\begin{array}{l}\text { Zooplankton assimilation } \\
\text { efficiency }\end{array}$ \\
\hline $\begin{array}{l}w_{S}{ }^{\mathrm{c}} \\
w_{L}{ }^{\mathrm{c}}\end{array}$ & $\begin{array}{l}1.0 \mathrm{~m} \mathrm{~d}^{-1} \\
10.0 \mathrm{~m} \mathrm{~d}^{-1}\end{array}$ & $\begin{array}{l}0.1 \mathrm{~m} \mathrm{~d}^{-1} \\
1.0 \mathrm{~m} \mathrm{~d}^{-1}\end{array}$ & $\begin{array}{l}\text { Small detritus sinking velocity } \\
\text { Large detritus sinking velocity }\end{array}$ \\
\hline
\end{tabular}

${ }^{a}$ Brush et al. (2002) showed that the temperature-dependent formulation of Eppley (1972) underestimates primary production. Even if a temperature dependency most probably exists in relation to the cell metabolism, the light intensity is the prior control factor. The use of a temperature-dependent formulation led to a latitudinal variation and underestimation (low temperature below the thermocline) of primary production. For a better analysis of the results, the temperature dependency of the maximum growth rate was totally removed.

${ }^{\mathrm{b}}$ See text for details.

${ }^{\mathrm{c}}$ Since the dead phytoplankton cells on one hand, and the zooplankton corps and fecal pellets on the other hand sink with distinct velocities due to their particles size difference, the zooplankton products are flowed to the large particle pool which sinks faster instead of the small particle pool. The aggregation process thus concerns only the phytoplankton living and dead cells. The sinking velocities proposed for such a configuration are $1 \mathrm{~m} \mathrm{~d}^{-1}$ for the small detritus pool (dead phytoplankton cells) and $10 \mathrm{~m} \mathrm{~d}^{-1}$ for the large detritus pool (zooplankton particles and phytoplankton aggregates).

Table A3: Common parameterization with Fennel et al. (2006)

\begin{tabular}{lll}
\hline Symbol & Value and Unit & Parameter \\
\hline$k_{N O 3}$ & $0.5 \mathrm{mmol} \mathrm{N} \mathrm{m}^{-3}$ & Half-saturation constant for nitrate uptake \\
$k_{N H 4}$ & $0.5 \mathrm{mmol} \mathrm{N} \mathrm{m}^{-3}$ & Half-saturation constant for ammonium uptake \\
$C N_{P}$ & $6.625[$ nondimensional] & Phytoplankton C to N ratio \\
$g_{\max }$ & $0.6 \mathrm{~d}^{-1}$ & Maximum grazing rate \\
$K_{p h y}$ & $2.0\left(\mathrm{mmol} \mathrm{N} \mathrm{m}^{-3}\right)^{2}$ & Half-saturation constant for grazing \\
$m_{p}$ & $0.15 \mathrm{~d}^{-1}$ & Phytoplankton mortality \\
$\tau$ & $\left.0.005(\mathrm{mmol} \mathrm{N} \mathrm{m})^{-3}\right)^{-1} \mathrm{~d}^{-1}$ & Aggregation parameter \\
$\theta_{\max }$ & $0.053 \mathrm{mgChl} a \mathrm{mgC}^{-1}$ & Maximum chlorophyll to phytoplankton ratio \\
$l_{B M}$ & $0.1 \mathrm{~d}^{-1}$ & Excretion rate due to basal metabolism \\
$l_{E}$ & $0.1 \mathrm{~d}^{-1}$ & Maximum rate of assimilation-related excretion \\
$m_{z}$ & $0.025(\mathrm{mmol} \mathrm{N} \mathrm{m})^{-3} \mathrm{~d}^{-1}$ & Zooplankton mortality \\
$w_{P h y}$ & $0.1 \mathrm{~m} \mathrm{~d}^{-1}$ & Phytoplankton sinking velocity \\
\hline
\end{tabular}




\section{References}

Admiraal, W., Peletier, H. and Lane, R., 1986. Nitrogen metabolism of marine planktonic diatoms; excretion, assimilation and cellular pools of free amino acids in seven species with different cell size. J. Exp. Mar. Biol. Ecol, 98: 241-263.

Aluwihare, L., Repeta, D. and Chen, R., 2002. Chemical composition and cycling of dissolved organic matter in the mid-Atlantic Bight. Deep-Sea Res, 49: 4421-4437.

Amon, R. and Benner, R., 1996. Bacterial Utilization of Different Size Classes of Dissolved Organic Matter. Limnol. Oceanogr., 41(1): 41-51.

Anderson, T. and Pondaven, P., 2003. Non-redfield carbon and nitrogen cycling in the Sargasso Sea: pelagic imbalances and export flux. Deep Sea Res. Part I, 50(5): 573-591.

Anderson, T. and Williams, P., 1998. Modelling the Seasonal Cycle of Dissolved Organic Carbon at Station E 1 in the English Channel. Estuar. Coast. Shelf Sci., 46(1): 93-109.

Baines, S. and Pace, M., 1991. The Production of Dissolved Organic Matter by Phytoplankton and its Importance to Bacteria: Patterns Across Marine and Freshwater Systems. Limnol. Oceanogr., 36(6): 1078-1090.

Bates, N. and Hansell, D., 1999. A high resolution study of surface layer hydrographic and biogeochemical properties between Chesapeake Bay and Bermuda. Mar. Chem., 67(1): 1-16.

Bauer, J. and Druffel, E., 1998. Ocean margins as a significance source of organic matter to the open ocean. Nature, 392: 482-485.

Bauer, J.E., E.R.M. Druffel, D.M. Wolgast, and S. Griffin, 2001. Cycling of dissolved and particulate organic radiocarbon in the northwest Atlantic continental margin. Global Biogeochem. Cycles, 15: 615-636.

Bauer, J.E., E.R.M. Druffel, D.M. Wolgast, and S. Griffin, 2002. Temporal and regional variability in sources and cycling of DOC and POC in the northwest Atlantic continental shelf and slope. Deep Sea Res., 49: 4387-4419.

Beardsley, R. and Boicourt, W., 1981. On estuarine and continental shelf circulation in the Middle Atlantic Bight. Evolution Phys. Oceanogr.: 198-233.

Benner, R., Pakulski, J., McCarthy, M., Hedges, J. and Hatcher, P., 1992. Bulk Chemical Characteristics of Dissolved Organic Matter in the Ocean. Science, 255(5051): 1561.

Berger, W., 1989. Global maps of ocean productivity. Productivity of the Oceans: Present and Past: New York (Wiley): 429-455.

Biddanda, B. and Benner, R., 1997. Carbon, Nitrogen, and Carbohydrate Fluxes During the Production of Particulate and Dissolved Organic Matter by Marine Phytoplankton. Limnol. Oceanogr., 42(3): 506518.

Biscaye, P. and Anderson, R., 1994. Fluxes of particulate matter on the slope of the southern Middle Atlantic Bight: SEEP-II. Deep Sea Res., Part II, 41(2-3): 459-509.

Biscaye, P., Anderson, R. and Deck, B., 1988. Fluxes of particles and constituents to the eastern United States continental slope and rise: SEEP-I. Cont. Shelf Res., 8: 855-904.

Biscaye, P., Flagg, C. and Falkowski, P., 1994. The shelf edge exchange processes experiment, SEEP-II: an introduction to hypotheses, results and conclusions. Deep Sea Res., Part II, 41(2-3): 231-252.

Bjørnsen, B., 1988. Phytoplankton exudation of organic matter: Why do healthy cells do it. Limnol. Oceanogr, 33: 151-154.

Bronk, D., Glibert, P. and Ward, B., 1994. Nitrogen Uptake, Dissolved Organic Nitrogen Release, and New Production. Science, 265(5180): 1843. 
Bronk, D. and Ward, B., 2000. Magnitude of Dissolved Organic Nitrogen Release Relative to Gross Nitrogen Uptake in Marine Systems. Limnol. Oceanogr., 45(8): 1879-1883.

Brush, M., Brawley, J., Nixon, S. and Kremer, J., 2002. Modeling phytoplankton production: problems with the Eppley curve and an empirical alternative. Mar. Ecol. Prog. Ser., 238: 31-45.

Carlson, C., 2002. Production and removal processes. Biogeochemistry of marine dissolved organic matter. Academic: $91-151$.

Chen, R.F., Fry, B., Hopkinson, C.S., Repeta, D.J., Peltzer, E.T., 1996. Dissolved organic carbon on Georges Bank. Cont. Shelf Res., 16: 409-420.

DeGrandpre, M., Olbu, G., Beatty, C. and Hammar, T., 2002. Air-sea CO 2 fluxes on the US Middle Atlantic Bight. Deep Sea Res., Part II, 49(20): 4355-4367.

Dinniman, M., Klinck, J. and Smith, W., 2003. Cross-shelf exchange in a model of the Ross Sea circulation and biogeochemistry. Deep Sea Res., Part II, 50: 3103-3120.

Druffel, E., Williams, P., Bauer, J. and Ertel, J., 1992. Cycling of Dissolved and Particulate Organic Matter in the Open Ocean. J. Geophys. Res., 97(C10): 15639-15659.

Eppley, R., 1972. Temperature and phytoplankton growth in the sea. Fish. bull., 70(4): 1063-85.

Fairall, C., Bradley, E., Hare, J., Grachev, A. and Edson, J., 2003. Bulk Parameterization of Air-Sea Fluxes: Updates and Verification for the COARE Algorithm. J. Clim., 16(4): 571-591.

Falkowski, P., Flagg, C., Rowe, G., Smith, S., Whitledge, T. and Wirick, C., 1988. The fate of a spring phytoplankton bloom: Export or oxidation. Cont. Shelf Res, 8(5-7): 457-484.

Fasham, M., Boyd, P. and Savidge, G., 1999. Modeling the Relative Contributions of Autotrophs and Heterotrophs to Carbon Flow at a Lagrangian JGOFS Station in the Northeast Atlantic: The Importance of DOC. Limnol. Oceanogr., 44(1): 80-94.

Fennel, K., Wilkin, J., Levin, J., Moisan, J., O'Reilly, J. and Haidvogel, D., 2006. Nitrogen cycling in the Middle Atlantic Bight: Results from a three-dimensional model and implications for the North Atlantic nitrogen budget. Global Biogeochem. Cycles, 20(3).

Fennel, K., Wilkin, J., Previdi, M. and Najjar, R. Submitted July 2008. Denitrification effects on air-sea $\mathrm{CO}_{2}$ flux in the coastal ocean: Simulations for the Northwest North Atlantic. Geophys. Res. Let.

Fisher, T.S., Hagy, J.D. and Rochelle-Newall, E., 1998. Dissolved and particulate organic carbon in Chesapeake Bay. Estuaries, 21(2): 215-229.

Flather, R., 1976. A tidal model of the northwest European continental shelf. Mem. Soc. R. Sci. Liege, 6(10): 141-164.

Fogg, G., 1966. The extracellular products of algae. Oceanogr. Mar. Biol. Ann. Rev., 4: 195-212.

Fogg, G., 1983. The ecological significance of extracellular products of phytoplankton photosynthesis. Bot. Mar., 26(1): 3-14.

Geider, R., MacIntyre, H. and Kana, T., 1997. Dynamic model of phytoplankton growth and acclimation: Responses of the balanced growth rate and the chlorophyll a: carbon ratio to light, nutrient-limitation and temperature. Mar. Ecol. Prog. Ser., 148(1): 187-200.

Gelinas, Y., Baldock, J. and Hedges, J., 2001. Organic Carbon Composition of Marine Sediments: Effect of Oxygen Exposure on Oil Generation Potential. Science, 294: 145-148.

Haidvogel, D., Arango, H., Hedstrom, K., Beckmann, A., Malanotte-Rizzoli, P. and Shchepetkin, A., 2000. Model evaluation experiments in the North Atlantic Basin: simulations in nonlinear terrainfollowing coordinates. Dyn. Atm. Oceans, 32(3): 239-281.

Haidvogel, D.B., H. Arango, W.P. Budgell, B.D. Cornuelle, E. Curchitser, E. Di Lorenzo, K. Fennel, W.R. Geyer, A.J. Hermann, L. Lanerolle, J. Levin, J.C. McWilliams, A.J. Miller, A.M. Moore, T.M. Powell, A.F. Shchepetkin, C.R. Sherwood, R.P. Signell, J.C. Warner, and J. Wilkin., 2007. Regional 
Ocean Forecasting in Terrain-following Coordinates: Model Formulation and Skill Assessment. J. comput. phys., In press.

Hansell, D., 2002. DOC in the global ocean cycle. In: D. Hansell and C. Carlson (Eds.), Biogeochemistry of Marine Dissolved Organic Matter. Academic Press, New-York, pp. 685-716.

Harding, L., Magnuson, A. and Mallonee, M., 2005. SeaWiFS retrievals of chlorophyll in Chesapeake Bay and the mid-Atlantic bight. Estuar. Coast. Shelf Sci.

Harvey, H. and Mannino, A., 2001. The chemical composition and cycling of particulate and macromolecular dissolved organic matter in temperate estuaries as revealed by molecular organic tracers. Org. Geochem., 32(4): 527-542.

Harvey, H., Tuttle, J. and Bell, J., 1995. Kinetics of phytoplankton decay during simulated sedimentation: Changes in biochemical composition and microbial activity under oxic and anoxic conditions. Geochim. Cosmochim. Acta, 59(16): 3367-3377.

Hasegawa, T., Koike, I. and Mukai, H., 2001. Fate of food nitrogen in marine copepods. Mar. Ecol. Prog. Ser., 210: 167-174.

Hellebust, J., 1965. Excretion of Some Organic Compounds by Marine Phytoplankton. Limnol. Oceanogr., 10(2): 192-206.

Henrichs, S. and Reeburgh, W., 1987. Anaerobic mineralization of marine sediment organic matter: Rates and the role of anaerobic processes in the oceanic carbon economy. Geomicrobiol. J, 5(19): 1-237.

Hofmann, E., J.-N. Druon, K. Fennel, M. Friedrichs, D. Haidvogel, C. Lee, A. Mannino, C. McClain, R. Najjar, J. O’Reilly, D. Pollard, M. Previdi, S. Seitzinger, J. Siewert, S. Signorini and J. Wilkin. 2008. Eastern U.S. Continental Shelf Carbon Budget: Integrating Models, Data Assimilation, and Analysis. Oceanography, 21: 86-104.

Hopkinson, C., Fry, B. and Nolin, A., 1997. Stoichiometry of dissolved organic matter dynamics on the continental shelf of the northeastern USA. Cont. Shelf Res., 17(5): 473-489.

Hopkinson, C.S., Vallino, J.J. and Nolin, A., 2002. Decomposition of dissolved organic matter from the continental margin. Deep-Sea Research Part Ii-Topical Studies in Oceanography, 49(20): 44614478.

Ianson, D. and Allen, S., 2002. A two-dimensional nitrogen and carbon flux model in a coastal upwelling region. Global Biogeochem. Cycles, 16(1): 1011.

Jensen, L., 1983. Phytoplankton release of extracellular organic carbon, molecular weight composition, and bacterial assimilation. Mar. Ecol. Prog. Ser., 11(1): 39-48.

Joliff, J., Kindle, J.C., Shulman, I., Penta, B. Friedrichs, M.A.M., Helber, R. Arnone, R.A., 2007. Summary diagrams for coupled hydrodynamic-ecosystem model skill assessment. J. Mar. Sys., submitted to a special issue on biological-physical model skill assessment.

Kantha, L. and Clayson, C., 1994. An improved mixed layer model for geophysical applications. J. Geophys. Res., 99(C12): 25235-25266.

Lancelot, C., 1983. Factors affecting phytoplankton extracellular release in the Southern Bight of the North Sea. Mar. Ecol. Prog. Ser., 12(2): 115-121.

Lancelot, C., 1984. Extracellular release of small and large molecules by phytoplankton in the southern Bight of the North Sea. Estuar. Coast. Shelf Sci., 18(1): 65-77.

Lancelot, C. and Billen, G., 1985. Carbon-nitrogen relationships in nutrient metabolism of coastal marine ecosystems. Adv. aquat. microbiol., 3: 263-321.

Lancelot, C., Spitz, Y., Gypens, N., Ruddick, K., Becquevort, S., Rousseau, V., Lacroix, G. and Billen, G., 2005. Modelling diatom and Phaeocystis blooms and nutrient cycles in the Southern Bight of the North Sea: the MIRO model. Mar. Ecol. Prog. Ser., 289: 63-78. 
Ledwell, J., Watson, A. and Law, C., 1993. Evidence for slow mixing across the pycnocline from an openocean tracer-release experiment. Nature, 364(6439): 701-703.

Magnuson, A., Harding, L., Mallonee, M. and Adolf, J., 2004. Bio-optical model for Chesapeake Bay and the Middle Atlantic Bight. Estuar. Coast. Shelf Sci.

Mannino, A., 2000. Chemical Composition of Particulate and Macromolecular Dissolved Organic Matter in the Delaware Estuary and Experimental Diatom Blooms: Sources and Reactivity Patterns, research directed by Marine, Estuarine, Environmental Sciences Graduate Program.University of Maryland, College Park.

Mannino, A. and Harvey, H.R., 2000a. Biochemical composition of particles and dissolved organic matter along an estuarine gradient: Sources and implications for DOM reactivity. Limnol. Oceanogr., 45(4): 775-788.

Mannino, A. and Harvey, H.R., 2000b. Terrigenous dissolved organic matter along an estuarine gradient and its flux to the coastal ocean. Org. Geochem., 31(12): 1611-1625.

Mannino, A., Russ, M.E. and Hooker, S.B., 2008. Algorithm development and validation for satellitederived distributions of DOC and CDOM in the U.S. Middle Atlantic Bight, J. Geophys. Res., 113, C07051, doi:10.1029/2007JC004493.

Marañón, E., Cermeno, P., Fernandez, E., Rodriguez, J. and Zabala, L., 2004. Significance and mechanisms of photosynthetic production of dissolved organic carbon in a coastal eutrophic ecosystem. Limnol. Oceanogr., 49(5): 1652-1666.

Marchesiello, P., McWilliams, J. and Shchepetkin, A., 2003. Equilibrium Structure and Dynamics of the California Current System. J. Phys. Oceanogr., 33(4): 753-783.

Mayer, L., Benninger, L., Bock, M., DeMaster, D., Roberts, Q. and Martens, C., 2002. Mineral associations and nutritional quality of organic matter in shelf and upper slope sediments off Cape Hatteras, USA: a case of unusually high loadings. Deep Sea Res., Part II, 49(20): 4587-4597.

Mellor, G. and Yamada, T., 1982. Development of a turbulence closure model for geophysical fluid problems. Rev. Geophy. Space Phys., 20: 851-875.

Mitra, S., Bianchi, T., Guo, L. and Santschi, P., 2000. Terrestrially derived dissolved organic matter in the Chesapeake Bay and the Middle Atlantic Bight. Geochim. Cosmochim. Acta, 64(20): 3547-3557.

Møller, E., 2005. Sloppy feeding in marine copepods: prey-size-dependent production of dissolved organic carbon. J. Plankton Res., 27(1): 27.

Møller, E., Thor, P. and Nielsen, T., 2003. Production of DOC by Calanus finmarchicus, C. glacialis and C. hyperboreus through sloppy feeding and leakage from fecal pellets. Mar. Ecol. Prog. Ser., 262: 185191.

Mouw, C. and Yoder, J., 2005. Primary production calculations in the Mid-Atlantic Bight, including effects of phytoplankton community size structure. Limnol. Oceanogr., 50(4): 1232-1243.

Nagata, T., 2000. Production mechanisms of dissolved organic matter. In: D. Kirchman (Ed.), Microbial ecology of the oceans. Wiley, New-York, pp. 121-152.

Norrman, B., Zweifel, U., Hopkinson Jr, C. and Fry, B., 1995. Production and Utilization of Dissolved Organic Carbon During an Experimental Diatom Bloom. Limnol. Oceanogr., 40(5): 898-907.

O'Reilly, J. and Busch, D., 1984. Phytoplankton primary production on the northwestern Atlantic shelf. Rapp. P.-v. Reun. Cons. Int. Explor. Mer, 183: 255-268.

O’Reilly, J., Evans-Zetlin, C. and Busch, D., 1987. Primary production. Chapter 21. In: R. Backus (Ed.), Georges Bank. MIT Press, Cambridge, MA, pp. 220-233.

Obernosterer, I. and Herndl, G., 1995. Phytoplankton extracellular release and bacterial growth: Dependence on the inorganic N: P ratio. Mar. Ecol. Prog. Ser., 116(1): 247-257. 
Peliz, A., Dubert, J., Haidvogel, D. and Le Cann, B., 2003. Generation and unstable evolution of a densitydriven eastern poleward current: The Iberian Poleward Current. J. Geophys. Res, 108: 3268.

Peterson, E., 1999. Benthic shear stress and sediment condition. Aquac. Eng., 21(2): 85-111.

Ploug, H. and Grossart, H., 2000. Bacterial Growth and Grazing on Diatom Aggregates: Respiratory Carbon Turnover as a Function of Aggregate Size and Sinking Velocity. Limnol. Oceanogr., 45(7): 14671475.

Pomeroy, L., Wiebe, W., Deibel, D., Thompson, R., Rowe, G. and Palkulski, J., 1991. Bacterial responses to temperature and substrate concentration during the Newfoundland spring bloom. Mar. Ecol. Prog. Ser, 75: 143-159.

Popova, E. and Anderson, T., 2002. Impact of including dissolved organic matter in a global ocean box model on simulated distributions and fluxes of carbon and nitrogen. Geophys. Res. Lett., 29(9): 171 .

Raick, C., Delhez, E., Soetaert, K. and Gregoire, M., 2005. Study of the seasonal cycle of the biogeochemical processes in the Ligurian Sea using a 1D interdisciplinary model. J. Mar. Sys.

Redalje, D., Lohrenz, S., Verity, P. and Flagg, C., 2002. Phytoplankton dynamics within a discrete water mass off Cape Hatteras, North Carolina: the Lagrangian experiment. Deep Sea Res., Part II, 49(20): 4511-4531.

Ryan, J., Yoder, J. and Cornillon, P., 1999. Enhanced Chlorophyll at the Shelfbreak of the Mid-Atlantic Bight and Georges Bank during the Spring Transition. Limnol. Oceanogr., 44(1): 1-11.

Sambrotto, R., Savidge, G., Robinson, C., Boyd, P., Takahashi, T., Karl, D., Langdon, C., Chipman, D., Marra, J. and Codispoti, L., 1993. Elevated consumption of carbon relative to nitrogen in the surface ocean. Nature, 363: 248-250.

Santschi, P., Guo, L., Baskaran, M., Trumbore, S., Southon, J., Bianchi, T., Honeyman, B. and Cifuentes, L., 1995. Isotopic evidence for the contemporary origin of high-molecular weight organic matter in oceanic environments. Geochim. Cosmochim. Acta, 59(3): 625-631.

Schaff, T., Levin, L., Blair, N., DeMaster, D., Pope, R. and Boehme, S., 1992. Spatial heterogeneity of benthos on the Carolina continental slope: large $(100 \mathrm{~km})$-scale variation. Mar. Ecol. Prog. Ser, 88: 143-160.

Schollaert, S., Rossby, T. and Yoder, J., 2003. Gulf Stream cross-frontal exchange: possible mechanisms to explain interannual variations in phytoplankton chlorophyll in the Slope Sea during the SeaWiFS years. Deep-Sea Research.

Seitzinger, S. and Sanders, R., 1999. Atmospheric Inputs of Dissolved Organic Nitrogen Stimulate Estuarine Bacteria and Phytoplankton. Limnol. Oceanogr., 44(3): 721-730.

Sharp, J., Culberson, C. and Church, T., 1982. The Chemistry of the Delaware Estuary. General Considerations. Limnology and Oceanography, 27(6): 1015-1028.

Six, K. and Maier-Reimer, E., 1996. Effects of plankton dynamics on seasonal carbon fluxes in an ocean general circulation model. Global Biogeochem. Cycles, 10(4): 559-583.

Smith, D., Simon, M., Alldredge, A. and Azam, F., 1992. Intense hydrolytic enzyme activity on marine aggregates and implications for rapid particle dissolution. Nature, 359(6391): 139-142.

Søndergaard, M., Williams, P., Cauwet, G., Riemann, B., Robinson, C., Terzic, S., Woodward, E. and Worm, J., 2000. Net Accumulation and Flux of Dissolved Organic Carbon and Dissolved Organic Nitrogen in Marine Plankton Communities. Limnol. Oceanogr., 45(5): 1097-1111.

Taylor, G.T., Way, J. and Scranton, M.I., 2003. Planktonic carbon cycling and transport in surface waters of the highly urbanized Hudson River estuary. Limnol. Oceanogr., 48(5): 1779-1795.

Thingstad, T., Hagstrom, A. and Rassoulzadegan, F., 1997. Accumulation of Degradable DOC in Surface Waters: Is it Caused by a Malfunctioning Microbial Loop? Limnol. Oceanogr., 42(2): 398-404. 
Thomas, C., Blair, N., Alperin, M., DeMaster, D., Jahnke, R., Martens, C. and Mayer, L., 2002. Organic carbon deposition on the North Carolina continental slope off Cape Hatteras (USA). Deep Sea Res., Part II, 49(20): 4687-4709.

USECoS, 2007. Eastern U.S. Continental Shelf Carbon Budget: Integrating Models, Data Assimilation, and Analysis. Oceanography, In press.

Varela, M., Barquero, S., Bode, A., Fernandez, E., Gonzalez, N., Teira, E. and Varela, M., 2003. Microplanktonic regeneration of ammonium and dissolved organic nitrogen in the upwelling area of the NW of Spain: relationships with dissolved organic carbon production and phytoplankton sizestructure. J. Plankton Res., 25(7): 719.

Verity, P., Redalje, D., Lohrenz, S., Flagg, C. and Hristov, R., 2002. Coupling between primary production and pelagic consumption in temperate ocean margin pelagic ecosystems. Deep Sea Res., Part II, 49(20): 4553-4569.

Vlahos, P., Chen, R.F. and Repeta, D.J., 2002. Dissolved organic carbon in the Mid-Atlantic Bight. Deep Sea Res., Part II, 49(20): 4369-4385.

Walsh, J., 1994. Particle export at Cape Hatteras. Deep Sea Res., Part II, 41(2): 603-628.

Warner, J., Sherwood, C., Arango, H. and Signell, R., 2005. Performance of four turbulence closure models implemented using a generic length scale method. Ocean Modelling, 8: 81-113.

Wilkin, J., 2006. The Summertime Heat Budget and Circulation of Southeast New England Shelf Waters. J. Phys. Oceanogr., 36(11): 1997-2011.

Williams, P., 1990. The importance of losses during microbial growth: commentary on the physiology, measurement and ecology of the release of dissolved organic material. Mar. microb. Fd Webs, 4(2): 175-206. 

The public reporting burden for this collection of information is estimated to average 1 hour per response, including the time for reviewing instructions, searching existing

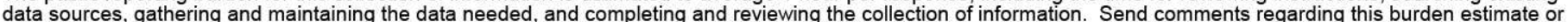

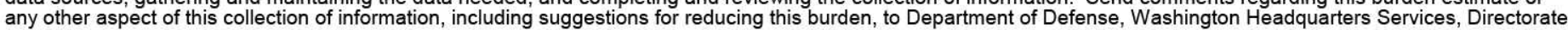
for Information Operations and Reports (0704-0188), 1215 Jefferson Davis Highway, Suite 1204, Arlington, VA 22202-4302. Respondents should be aware that notwithstanding any other provision of law, no person shall be subject to any penalty for failing to comply with a collection of information if it does not display a currently valid OMB control number.

PLEASE DO NOT RETURN YOUR FORM TO THE ABOVE ADDRESS.

1. REPORT DATE (DD-MM-YYYY) 1 2. REPORT TYPE 3. DATES COVERED (FrOm - TO) 12-02-2009

Technical Memorandum

4. TITLE AND SUBTITLE

Modeling the Dynamics and Export of Dissolved Organic

Matter in the Northeastern U.S. Continental Shelf

5a. CONTRACT NUMBER

5b. GRANT NUMBER

5c. PROGRAM ELEMENT NUMBER

6. AUTHOR(S)

J.N. Druon, A. Mannino, S. Signorini, C.R. McClain, M. Friedrichs,

J. Wilkin, and K. Fennel

5d. PROJECT NUMBER

5e. TASK NUMBER

5f. WORK UNIT NUMBER

7. PERFORMING ORGANIZATION NAME(S) AND ADDRESS(ES)

Goddard Space Flight Center

Greenbelt, MD 20771

8. PERFORMING ORGANIZATION REPORT NUMBER

200900837

9. SPONSORING/MONITORING AGENCY NAME(S) AND ADDRESS(ES)

10. SPONSORING/MONITOR'S ACRONYM(S)

National Aeronautics and Space Administration

Washington, DC 20546-0001

11. SPONSORING/MONITORING REPORT NUMBER

NASA TM-2009-214177

\section{DISTRIBUTION/AVAILABILITY STATEMENT}

Unclassified-Unlimited, Subject Catagory: 48

Report available from NASA Centerfor Aerospace Information, 7115 Standard Drive, Hanover, MD 21076. (301) 621-0390

\section{SUPPLEMENTARY NOTES S.R. Signorini: SAIC, Beltsville, MD; M. Friedrichs: Virginia Institute of Marine Science, The} College of William \& Mary, Gloucester Point, VA; J. Wilkin: Rutgers University, New Brunswick, NJ; K. Fennel: Dalhousie University, Halifax, Nova Scotia, Canada

14. ABSTRACT Continental shelves are believed to play a major role in carbon cycling due to their high productivity. Particulate organic carbon (POC) burial has been included in models as a carbon sink, but we show here that seasonally produced dissolved organic carbon (DOC) on the shelf can be exported to the open ocean by horizontal transport at similar rates (1-2 mol C m-2 yr -1) in the southern U.S. Mid-Atlantic Bight (MAB). The dissolved organic matter (DOM) model imbedded in a coupled circulation-biogeochemical model reveals a double dynamics: the progressive release of dissolved organic nitrogen (DON) in the upper layer during summer increases the regenerated primary production by 30 to $300 \%$, which, in turns, enhances the DOC production mainly from phytoplankton exudation in the upper layer and solubilization of particulate organic matter (POM) deeper in the water column. This analysis suggests that DOM is a key element for better representing the ecosystem functioning and organic fluxes in models because DOM (1) is a major organic pool directly related to primary production, (2) decouples partially the carbon and nitrogen cycles (through carbon excess uptake, POM solubilization and DOM mineralization) and (3) is intimately linked to the residence time of water masses for its distribution and export.

\section{SUBJECT TERMS}

Ocean color, SeaWiFS, Modeling, Dissolved organic matter, dissolved organic carbon, dissolved organic nitrogen, carbon burial, continental shelf, mid-Atlantic Bight, transport, export, model, biogeochemistry

\begin{tabular}{|l|l|l|l|}
\hline \multicolumn{2}{|l|}{ 16. SECURITY CLASSIFICATION OF: } & 17. LIMITATION OF \\
ABSTRACT
\end{tabular}

\begin{tabular}{|c|l|}
\begin{tabular}{|c|} 
18. NUMBER \\
OF \\
PAGES
\end{tabular} & 19a. NAME OF RESPONSIBLE PERSON \\
\cline { 2 - 2 } 42 & $\begin{array}{l}\text { Charles R. McClain } \\
\text { (301) } 286-5377\end{array}$ \\
\hline
\end{tabular}



